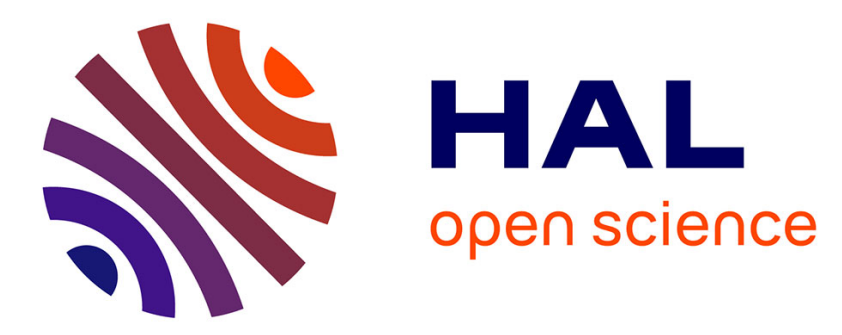

\title{
Revisiting the Malvinas Current upper circulation and water masses using a highresolution ocean reanalysis
}

Camila Artana, Christine Provost, Léa Poli, Ramiro Ferrari, Jean-Michel Lellouche

\section{- To cite this version:}

Camila Artana, Christine Provost, Léa Poli, Ramiro Ferrari, Jean-Michel Lellouche. Revisiting the Malvinas Current upper circulation and water masses using a highresolution ocean reanalysis. Journal of Geophysical Research. Oceans, 2021, 126 (6), 10.1029/2021JC017271 • hal-03247496

\section{HAL Id: hal-03247496 \\ https://hal.sorbonne-universite.fr/hal-03247496}

Submitted on 3 Jun 2021

HAL is a multi-disciplinary open access archive for the deposit and dissemination of scientific research documents, whether they are published or not. The documents may come from teaching and research institutions in France or abroad, or from public or private research centers.
L'archive ouverte pluridisciplinaire HAL, est destinée au dépôt et à la diffusion de documents scientifiques de niveau recherche, publiés ou non, émanant des établissements d'enseignement et de recherche français ou étrangers, des laboratoires publics ou privés. 
1 Revisiting the Malvinas Current upper circulation and water masses using a high -

2

3

4

5

$6{ }^{1}$ : MERCATOR-OCEAN, Parc Technologique du Canal, 8-10 rue Hermès, Ramonville Saint 7 Agne, France.

$8{ }^{2}$ : Laboratoire LOCEAN-IPSL, Sorbonne Université (UPMC, Univ. Paris 6), CNRS, IRD, 9 MNHN, Paris, France.

\section{resolution ocean reanalysis}

\author{
Artana Camila ${ }^{1}$, Christine Provost $^{2}$, Lea Poli $^{2}$, Ramiro Ferrari $^{3}$, Jean-Michel Lellouche ${ }^{1}$
}

${ }^{3}$ : CIMA/CONICET-UBA and UMI IFAECI-3351, Buenos Aires, Argentina

\section{Key points:}

- The Malvinas Current is rather steady: volume transport time series have little seasonality, no trend and small relative standard deviations

- The upper $900 \mathrm{~m}$ transport mean decreases from $40 \mathrm{~Sv}$ at $51^{\circ} \mathrm{S}$ to $35 \mathrm{~Sv}$ at $41^{\circ} \mathrm{S}$ indicating offshore leakage along the Malvinas Current path.

- The Malvinas Plateau is a key region for water mass modification through eddy mixing and deep winter mixed layers 


\section{Abstract:}

We use 25 years of a high-resolution ocean reanalysis $\left(1 / 12^{\circ}\right)$ to revisit the Malvinas Current (MC) from the South (Drake Passage) to the North (Brazil-Malvinas Confluence) from the synoptic to interannual time scales. The Malvinas Plateau is home to active eddy mixing, eddy dissipation and deep winter mixed layers occasionally reaching $600 \mathrm{~m}$ depth. The MC is organized in two jets which merge around $44^{\circ} \mathrm{S}$ as the continental slope steepens. The upper $900 \mathrm{~m}$ transport mean decreases from $40 \mathrm{~Sv}$ at $51^{\circ} \mathrm{S}$ to $35 \mathrm{~Sv}$ at $41^{\circ} \mathrm{S}$ indicating offshore leakage along the MC path. The MC plays a minor role in the velocity variations observed at the Confluence at seasonal and interannual scales; those are driven by changes in the intensity of the Brazil Current over the slope $\left(34-36^{\circ} \mathrm{S}\right)$.

Computing MC transport time series at different latitudes requires care because the section eastern limits are embedded in an energetic region. Transport time series were produced at selected latitudes using different criteria and showed common features. They show little seasonality (relative seasonal standard deviation of $2 \%$ ) and no significant trend. The MC is a steady current: the relative standard deviation is on the order of $10 \%$ increasing to $20 \%$ near and on the Malvinas Plateau and near the Confluence. In contrast, velocity trends are large in the Brazil Current with the overshoot migrating southward. The associated increase in mesoscale activity south of $44^{\circ} \mathrm{S}$ in the Argentine Basin might contribute to blocking events occasionally reducing the MC transport.

52 
58

59

60 The Malvinas Current (MC) is a branch of the Antarctic Circumpolar Current and flows 61 northward along the Patagonian slope. We revisit the Malvinas Current upper circulation and 62

63

64

65

66

67

68

69

70

71

72

73

74

75

76

77

78

79

80

81

82

83

84

85

86

87

88

89

90

91

92

93

94

water masses using a high-resolution ocean reanalysis from 1993 to 2017 . The MC is a strong and rather steady current with little seasonality and no significant trend. The mean MC volume transport reduces from south to north by about $14 \%$, indicating an offshore leakage along its path. The upper $500 \mathrm{~m}$ MC waters underwent a freshening of $0.1 \mathrm{psu} / \mathrm{dec}$ de.

6

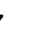

(1)

0




\section{Introduction}

The Malvinas Current (MC), a major western boundary current of the South Atlantic, is the northernmost meander of the northern branch of the Antarctic Circumpolar Current (ACC), the Subantarctic Front (SAF). The North Scotia Ridge in Drake Passage (Figure 1 a) acts as a barrier to the ACC fronts forcing the SAF and Polar Front (PF) branches to deviate to the north. The two SAF branches (SAF-N and SAF-M) cross the North Scotia Ridge west $(600 \mathrm{~m})$ and east (2000 m) of Burdwood Bank (WBB and EBB respectively), while the two northern branches of the PF (PF-M and PF-N) proceed through Shag Rocks Passage (3200 m, SRP) (Figure 1a). Subsequently, the SAF branches cross the shallow Malvinas Plateau $(<3000 \mathrm{~m})$ and continue their path northward forming the Malvinas Current (MC), while the PF follows an eastward path along the Malvinas Escarpment (Figure 1a). The MC is an equivalentbarotropic current that flows along the Patagonian continental slope with surface velocities of the order of $60 \mathrm{~cm} / \mathrm{s}$ (Figure 1b). Observations suggest that the MC is organized in two narrow jets at $45^{\circ} \mathrm{S}$ (Piola et al., 2013, Frey et al., 2021). Poli et al. (2020) showed that shelf break trapped waves modulate the intensity of the inner jet -SAF-N branch- while slow waves propagating from the Malvinas Escarpment and the Drake Passage modify velocities in the main jet -SAF-M branch- (Figure 2a). The Malvinas Current is concentrated in a narrow single jet at $41^{\circ} \mathrm{S}$ and encounters the Brazil Current (BC) at $38^{\circ} \mathrm{S}$. Then part of the $\mathrm{BC}$, referred to as the overshoot of the $\mathrm{BC}$, flows southward and returns to the northeast at about $45^{\circ} \mathrm{S}$ while the MC splits in two branches: the inner branch keeps flowing northward sinking below the BC while the outer branch describes a sharp cyclonic loop and returns southward (Provost et al., 1995; Artana et al., 2019a). The southward return flow is referred to as the Malvinas Return Flow (Peterson and Whitworth, 1989). The region of the confluence is known as the Brazil Malvinas Confluence and is associated with lateral temperature gradients as high as $1^{\circ} \mathrm{C}$ per 
119100 m (Gordon and Greengrove, 1986; Barré et al., 2006) and large meso and submesoscale eddies and filaments.

Interestingly, although the MC presents moderate Eddy Kinetic Energy (EKE) values ( $\sqrt{E K E}$ of $15 \mathrm{~cm} / \mathrm{s})$, it connects two of the most energetic oceanic regions: the Drake Passage $(\sqrt{E K E}$ of $30 \mathrm{~cm} / \mathrm{s})$ and the Brazil Malvinas Confluence $(\sqrt{E K E}$ of $45 \mathrm{~cm} / \mathrm{s}$, Figure $1 \mathrm{c})$. Some of the Drake Passage EKE leaks across the North Scotia Ridge through the EBB and SRP and reduces over the Malvinas Plateau through dissipation and mixing (Artana et al., 2016, Figure 2a). As a result, $\sqrt{E K E}$ values over the Malvinas Plateau are in the order of $15 \mathrm{~cm} / \mathrm{s}$ (Figure 1c). At the exit of the Malvinas Plateau, the MC is particularly exposed to mesoscale activity propagating westward along the Malvinas Escarpment. Around once a year the MC is cut from the ACC due to anticyclonic anomalies from the deep Argentine Basin (red in Figure 2b, Artana et al., 2016 and Artana et al., 2018a). These blocking events are short-lived (from 10 to 35 days) and the MC downstream does not collapse rather becomes the western boundary of a recirculating cyclonic cell. Occasionally, the PF-N meanders north of the Malvinas Plateau and waters from the South of the Polar Front (PF) are injected into the MC as pulses or feeding events (blue in Figure 2b, Artana et al., 2018c). Polar waters accumulate in the recirculation region between the MC and the Malvinas Return Flow. Low frequency variations in the water characteristics of the recirculation region are consistent with changes in the recurrence of feeding events.

137 The MC is the unique current in the southern hemisphere that carries Subantarctic Surface Water and Antarctic Intermediate Waters to latitudes as low as $38^{\circ} \mathrm{S}$. These cold and nutrient rich waters are key for the development of rich ecosystems along the Patagonian shelf which

140 sustain one of the largest fisheries of the world (Romero et al., 2006; Valla and Piola, 2015).

141 The modification of water properties along the MC path is poorly understood and an evaluation of the MC transport over its latitudinal range is missing. To the date, the only volume transport 
143 time series of the $\mathrm{MC}$ have been produced at $41^{\circ} \mathrm{S}$ near the Brazil Malvinas Confluence where

144 mooring data were gathered at different periods (Vivier and Provost, 1999a; Spadone and

145 Provost, 2009; Paniagua et al., 2018). The mooring data were combined with satellite altimetry

146 data to produce a 25 year-long transport time series in the upper $1500 \mathrm{~m}$ (Artana et al., 2018a).

147 Maxima and minima of the MC transport at $41^{\circ} \mathrm{S}$ were not associated with variations of the

148 ACC, rather with eddies coming from the Argentine Basin: maxima were associated with 149 cyclonic eddies detached from the Polar Front (in blue in Figure 2c) and minima with large 150 anticyclonic anomalies from the Brazil Current (in red in Figure 2c).

151 Here we revisit the Malvinas Current from its southern part to its northernmost tip from 152 synoptic to interannual time scales using 25 years of the high-resolution Mercator Ocean 153 reanalysis GLORYS12. This reanalysis has shown skills in reproducing the hydrography and 154 circulation of the Argentine Basin in the upper layers and proved to be a most valuable tool to 155 study the MC in this region where in situ observations are rather scarce (Artana et al., 2018b, 2018c, 2019a; Poli et al., 2020). We aim at assessing the MC transport at different latitudes and at documenting modification of $\mathrm{MC}$ water properties. We focus on the upper circulation and upper water masses of the MC all along its path. After a presentation of the reanalysis and its evaluation (section 2), we investigate the velocity structure along the continental slope and produce volume transport time series in the upper $900 \mathrm{~m}$ at different latitudes (section 3 ). Modifications of the Subantarctic Surface Water and Antarctic Intermediate Waters are examined in section 4 and their volume transport evolutions in section 5. Results are summarized in section 6 . 
We use daily means of 25 years (1993-2017) of high-resolution $\left(1 / 12^{\circ}\right)$ global Mercator Ocean reanalysis (hereafter, GLORYS12) from Copernicus Marine Environment Monitoring Service (CMEMS, http://marine.copernicus.eu/). GLORYS12 is based on the current real-time global high-resolution forecasting CMEMS system PSY4V3 (Lellouche et al., 2018). Compared to PSY4V3, GLORYS12 reanalysis uses the reprocessed atmospheric forcing coming from the global atmospheric reanalysis ERA-Interim and benefits from a few changes in the system settings about observation errors. The model has 50 vertical levels with 22 levels in the upper $100 \mathrm{~m}$ leading to a vertical resolution of $1 \mathrm{~m}$ in the upper levels and $450 \mathrm{~m}$ at $5000 \mathrm{~m}$ depth. The physical component of the model is the Nucleus for European Modeling of the Ocean platform (NEMO). The model assimilates observations using a reduced-order Kalman filter with a 3-D multivariate modal decomposition of the background error and a 7-day assimilation cycle (Lellouche et al., 2013). Along-track satellite altimetric data from CMEMS (Pujol et al., 2016), satellite sea surface temperature from NOAA, sea-ice concentration, and in situ temperature and salinity vertical profiles from the latest CORA in situ databases (Cabanes et al., 2013; Szekeley et al., 2016) are jointly assimilated. A 3D-VAR scheme provides an additional 3-D correction for the slowly evolving large-scale biases in temperature and salinity when enough observations are available (Lellouche et al., 2018).

\subsection{GLORYS12 evaluation in the Southwestern Atlantic and Drake Passage}

In a previous work, Artana et al. (2018b) evaluated the performance of PSY4V3 in the Southwestern Atlantic Ocean. Ten years (2007-2016) of model outputs were compared to assimilated satellite and Argo float data and to independent in situ data that were not assimilated. The comparison showed that the PSY4V3 system correctly reproduces the general 
circulation and the complex hydrographic features of the Southwestern Atlantic Ocean upper layers. The authors found an excellent agreement between model and satellite sea surface height (Artana et al., 2018c). In a subsequent work general agreement between GLORYS12 and PSY4V3 was found, and comparisons with observations showed that GLORYS12 is closer to the data than PSY4V3 in the region of interest (Artana, et al., 2018c).

An extensive evaluation of GLORYS12 velocities was also performed at Drake Passage 197 (Artana et al., 2019b). GLORYS12 velocities compared well with independent current meter data in the water column and $50 \mathrm{~m}$ above the seafloor. The GLORYS12 total ACC volume transport has a mean of 155 (3 Sv being the uncertainty on the mean) and a standard deviation (std) of 6.7 Sv over 25 years (Artana et al., 2019b).

Here we focus on the upper MC as GLORYS12 performance was only evaluated in the upper layers of the Southwestern Atlantic Ocean. We tentatively examined the stream function of the mean volume transport between the surface and the bottom in the Southwestern Atlantic Ocean: the total $\mathrm{MC}$ transport decreases from $75 \mathrm{~Sv}$ at $51^{\circ} \mathrm{S}$ to $55 \mathrm{~Sv}$ at $47^{\circ} \mathrm{S}$ and $50 \mathrm{~Sv}$ at 44.7 and $41^{\circ} \mathrm{S}$. These values are consistent with the few total volume transport estimates derived from in situ data (Peterson, 1992; Saunders and King, 1995; Maamaatuaiahutapu et al., 1998; Colin de Verdière and Ollitrault, 2016) (see supplementary material S1).

\section{The MC upper circulation}

\subsection{Surface velocity: Mean and variations}

210 The MC mean surface velocity structure evolves with the continental slope geometry (Figure

$211 \mathrm{bb}$, Figure 3). At $51^{\circ} \mathrm{S}$, over the Malvinas Plateau, the slope is gentle $(8 \mathrm{~m} / \mathrm{km})$, the mean MC 212 organized in two rather wide jets $(150 \mathrm{~km}$ and $200 \mathrm{~km}$, purple in Figure $3 \mathrm{~b})$ centered on local 213 gradient bathymetry maxima $(10 \mathrm{~m} / \mathrm{km})$ located on the 400 and $1500 \mathrm{~m}$ isobaths. The inner (20 $214 \mathrm{~cm} / \mathrm{s})$ and offshore jets $(25 \mathrm{~cm} / \mathrm{s})$ are associated with the SAF-N and the SAF-M respectively. 215 Further east, a smaller jet $(8 \mathrm{~cm} / \mathrm{s})$ above the $2000 \mathrm{~m}$ isobath corresponds to the northern branch 
216 of the PF. Further north, as the slope steepens, the jets narrow, intensify and then merge around $21744^{\circ} \mathrm{S}$ (Figure $1 \mathrm{~b}$ ). Between $51^{\circ} \mathrm{S}$ and $46^{\circ} \mathrm{S}$, the offshore jet is located above the $1500 / 1400 \mathrm{~m}$ 218 isobath while the inshore jet follows the shelf break which varies between 300 and $500 \mathrm{~m}$ 219 (green and orange sections in Figure 3). The mean surface velocity of the offshore jet increases 220 towards the north ranging from $25 \mathrm{~cm} / \mathrm{s}$ at $51^{\circ} \mathrm{S}$ to $40 \mathrm{~cm} / \mathrm{s}$ at $47^{\circ} \mathrm{S}$. In general, the mean surface velocities of the offshore jet are twice as large as those of the inshore jet. However, at $44.7^{\circ} \mathrm{S}$ where the MC transitions to a single jet regime as the slope steepens $(30 \mathrm{~m} / \mathrm{km})$, the two jets merge and the largest surface velocities $(58 \mathrm{~cm} / \mathrm{s}$ ) are found above $200 \mathrm{~m}$ (blue section in Figure 3). This is consistent with mean surface velocities derived from the mean dynamic topographyfrom Mulet et al. (2020) (see supplementary material S2) and a month-long record of ADCP observations above the $200 \mathrm{~m}$ isobath at $44.7^{\circ} \mathrm{S}$ which documented velocities as large as $68 \mathrm{~cm} / \mathrm{s}$ at $20 \mathrm{~m}$ depth (Saraceno et al., 2020).

Overall, the MC is a rather stable current with surface velocities presenting relatively homogeneous and small stds $(10 \mathrm{~cm} / \mathrm{s}$, Figures $1 \mathrm{c}$ and $3 \mathrm{~b})$. Std of the surface velocity is larger in the outer part of the sections, in particular at $51^{\circ} \mathrm{S}, 59^{\circ} \mathrm{W}$ and $41^{\circ} \mathrm{S}(\sim 15 \mathrm{~cm} / \mathrm{s}$, Figure $3 \mathrm{~d})$, which are under the influence of offshore perturbations (Figure 1c). The impact of the offshore mesoscale activity on the MC surface velocities is illustrated in a synoptic situation in the supplementary material S3.

234 Surface velocities do not change in the MC at seasonal time scale while they increase by 15 $235 \mathrm{~cm} / \mathrm{s}$ in summer at the BC and Brazil Malvinas Confluence (Figure 4a-b). The overshoot is 236 located 3 degrees further south in winter $\left(44^{\circ} \mathrm{S}-54^{\circ} \mathrm{W}\right)$ than in summer. The velocities in the overshoot are larger in winter $(+15 \mathrm{~cm} / \mathrm{s})$ suggesting that the $\mathrm{BC}$ summer intensification advects into a winter intensification of the overshoot. The SAF remains at a similar position regardless of the season and the Subtropical Front pivots over a point located at $38^{\circ} \mathrm{S}$ over the

240 slope (1000 m isobath) as observed in Saraceno et al. (2005). In relation with the overshoot 
seasonal displacement, the offshore EKE shows large values further south in winter (not shown).

243 Surface velocity trends over the 25 years are relatively small, although significant in the MC, 244 with a weakening $(-2 \mathrm{~cm} / \mathrm{s} /$ decade $)$ in the inshore part of the $\mathrm{MC}$ and a strengthening in the 245 offshore part ( $2 \mathrm{~cm} / \mathrm{s} /$ decade) possibly indicating an offshore displacement of $20 \mathrm{~km}$ (Figure $2464 \mathrm{c})$. The surface velocity trend also suggests a small shift in the position of the northern branch 247 Polar Front over the Malvinas Plateau of $60 \mathrm{~km}$ westward. Interestingly the EKE surface trends 248 are positive over EBB and the eastward flank of SRP $\left(50 \mathrm{~cm}^{2} / \mathrm{s}^{2} /\right.$ decade $)$ suggesting an increase 249 of the EKE leakage towards the Malvinas Plateau.

250 Surface velocity trends over the slope are large around $38^{\circ} \mathrm{S}(10 \mathrm{~cm} / \mathrm{s} /$ decade $)$ and reflect the 251 southward displacement of the confluence associated with an intensification of the southward 252 flow of the BC as observed in Artana et al. (2019a). The large cyclonic structure centered at $55^{\circ} \mathrm{W}-43^{\circ} \mathrm{S}$ in the surface velocity trend indicates a southward displacement of the BC overshoot with an intensification of the surface velocities south of $44^{\circ} \mathrm{S}$ (Figure 4c). As a result, 255 the EKE trends are positive and large $\left(150 \mathrm{~cm}^{2} / \mathrm{s}^{2} /\right.$ decade $)$ in the southward part of the 256 Argentine Deep Basin (Figure 4d).

257 The MC presents a barotropic equivalent structure (Vivier and Provost, 1999b) and the features 258 at depth are consistent with those observed at the surface as shown in the stream function of the mean volume transport in the upper $900 \mathrm{~m}$ (Figure 5).

\subsection{Volume transport in the upper $900 \mathrm{~m}$}

261 The MC mean transport in the upper $900 \mathrm{~m}$ at $44.7^{\circ} \mathrm{S}$ is about $37 \mathrm{~Sv}$ with a contribution of 3

262 Sv from WBB, $23 \mathrm{~Sv}$ from EBB, and $11 \mathrm{~Sv}$ from SRP (Figure 5a, transport streamlines every $2635 \mathrm{~Sv}$ ). About two thirds of the full SRP transport follow the PF, turn eastward and do not reach 
mean transport $\left(20 \mathrm{~Sv}\right.$ at $\left.36^{\circ} \mathrm{S}\right)$. The upper $900 \mathrm{~m}$ transport does not change with seasons over the MC while it increases by $10 \mathrm{~Sv}$ over the $\mathrm{BC}$ in summer and by $5 \mathrm{~Sv}$ over the overshoot in winter (Figure 5b-c) in agreement with the surface velocity seasonality discussed in section 3.1. The transport seasonal behavior is robust: seasonal averages computed over different years yield similar results (not shown).

The MC transport does exhibit variations at interannual scale. As an example, we show the mean transports in 2015 and 2003 which correspond, respectively, to small (30 Sv) and large (40 Sv) values at $41^{\circ} \mathrm{S}$ (Artana et al., 2018a and 2019a). Interestingly the MC transport upstream, between 48 and $42^{\circ} \mathrm{S}$, is $5 \mathrm{~Sv}$ larger than the mean in 2015 and similar to the mean (35 Sv) in 2003 (Figure 5d-e). This example illustrates that the transport variations at $41^{\circ} \mathrm{S}$ do not reflect upstream MC transport changes rather local perturbations near the Confluence (as schematized in Figure 2c). Indeed, anticyclones from the overshoot reduced the transport by 5 Sv at $41^{\circ} \mathrm{S}$ in 2015 , while in 2003 cyclones from the south advected offshore over the $4000 \mathrm{~m}$ isobath locally reinforce the MC transport when they reached $41^{\circ} \mathrm{S}$ (Figure 5d-e; Artana et al., 2018c). The return flow of the Malvinas Current shows different behaviors in 2003 and 2015. While in 2003 the Malvinas Return Flow flows straightforward south towards the Malvinas Escarpment, in 2015 part of the Malvinas Return Flow turns northwestward following the BC overshoot.

MC volume transport time series in the upper $900 \mathrm{~m}$ were estimated at five latitudes in different ways to account for the difficulty in defining an eastern boundary to the sections. Indeed, if the section western boundary is straightforward, taken here as the $100 \mathrm{~m}$ isobath, the eastern limit is open and lies in an energetic environment. Sensitivity tests to the length of the sections were performed (extending and reducing the section length by $50 \mathrm{~km}$ ). Volume transports time series were estimated considering positive $(\mathrm{T}+)$ and both sign velocities $(\mathrm{T}+-)$. The times series are 
presented in supplementary S4 and their statistics in Table 1. From now on we only examine

$290(\mathrm{~T}+)$ time series as $(\mathrm{T}+)$ and $(\mathrm{T}+-)$ are highly correlated (the lowest correlation of 0.62 observed at $44.7^{\circ} \mathrm{S}$ results from the recurrent southward flow of the Malvinas Return Flow impinging on the eastern part of the section) and $(\mathrm{T}+)$ means are closer to the mean values shown in Figure 2935 a (being 6 to $10 \mathrm{~Sv}$ larger than $(\mathrm{T}+-))$. As expected, the std is largest (>8 Sv) at $41^{\circ} \mathrm{S}, 59^{\circ} \mathrm{W}$ and $51^{\circ} \mathrm{S}$ sections where the offshore side of the sections reaches a large EKE region (Table 1, Figure 1c). Correlations between transport time series from different latitudes are significant (above the 99\% confidence level) although relatively small because of the local mesoscale activity on the eastern boundary of each section (Table 2). The upper $900 \mathrm{~m}$ transport time series at EBB and SRP are not correlated with the transport of the sections located further north. This is consistent with Artana et al. (2016) who showed that an important part of the mesoscale activity coming from Drake Passage is damped out over the Malvinas Plateau (Figure 2a). The range of variations at synoptic scale is of the order of $30 \mathrm{~Sv}$. The transport varies over a relatively small range at seasonal scale $(<5 \mathrm{~Sv}$ on average) in contrast to the larger interannual variations (range larger than $10 \mathrm{~Sv}$ on average).

The MC carries several water masses that we examine focusing on their temporal and spatial 305 distribution, their modification and long-term changes.

\section{Water masses in the MC}

Following Maamaatuaiahutapu et al. (1994), several water masses are identified at $51^{\circ} \mathrm{S}$ (Figure 6a-c). The mean temperature and salinity of the upper $100 \mathrm{~m}\left(4.8^{\circ} \mathrm{C}\right.$ and $\left.34.05 \mathrm{psu}\right)$

309 correspond to the light Subantarctic Surface Water (SASW; $\sigma_{\theta}<27.00 \mathrm{~kg} / \mathrm{m}^{3}$ ). Below, three 310 varieties of AAIW can be distinguished (Provost et al., 1995): the light upper AAIW (AAIW$311 \mathrm{U})\left(27.00<\sigma_{\theta}<27.14 \mathrm{~kg} / \mathrm{m}^{3}\right.$ ), a central AAIW (AAIW-C, $27.14<\sigma_{\theta}<27.29 \mathrm{~kg} / \mathrm{m}^{3}$ ), and a 312 lower AAIW (AAIW-L, 27.29< $\sigma_{\theta}<27.35 \mathrm{~kg} / \mathrm{m}^{3}$ ). The AAIW-U and AAIW-C are classified 
314 Circumpolar Deep Waters (UCDW) correspond to potential density between 27.35 and 27.73

$315 \mathrm{~kg} / \mathrm{m}^{3}$. The std in salinity and density show a local maximum at the interface between the 316 AAIW and UCDW at depth of 34.25 and $34.32 \mathrm{psu}$ isohaline and 27.3 and $27.35 \mathrm{~kg} / \mathrm{m}^{3}$ 317 isopycnals (Figure 6f-g). The depth of AAIW-UCDW interface varies over a range of $200 \mathrm{~m}$.

318 In contrast, the std of potential temperature decreases monotonically with depth as AAIW and 319 UCDW have similar temperatures (between $2.7^{\circ} \mathrm{C}$ and $2.5^{\circ} \mathrm{C}$ ) (Figure 6a). The range in $\Theta / \mathrm{S}$ delimiting the AAIW-UCDW interface is shaded in Figure 6i.

\subsection{Spatial distribution of the SASW and AAIW layer (Malvinas Upper Waters)}

322

323

324 325
We focused on SASW and AAIW called hereafter MUW (for Malvinas Upper Waters). $\Theta / S$ criteria (in the range of the shaded area in Figure 6i) were used to define the lower boundary of the MUW layer. On average, the MUW occupy a thick layer $(>800 \mathrm{~m})$ reaching the surface along the Patagonian slope and Malvinas Plateau, and, a thinner layer isolated from the surface offshore (Figure 7a and b). The thin layer in the subtropical gyre $(<300 \mathrm{~m})$ is found at depth below $800 \mathrm{~m}$ and corresponds to eroded AAIW with Indian Ocean influence recirculating southward (Gordon et al., 1992; Maamaatuaiahutapu et al., 1998).

We computed the presence probability of the MUW in the upper $900 \mathrm{~m}$ over the 25 years (Figure 7c): 100\% means that these waters occupy the upper $900 \mathrm{~m}$ all the time. The MUW are mostly common (>90\% of occurrences) in the upper $900 \mathrm{~m}$ at EBB and all along the Patagonian continental slope south of $38^{\circ} \mathrm{S}$ (Figure 7c). The MUW water flow occurs primarily in a narrow band closely following the continental slope. 


\subsection{Modification through winter convection}

337

338

339

340

341

342

343

344

345

346

347

348

349

350

351

352

353

354

355

356

357

358

359

We investigate MUW modification through deep mixed layer formation. Two mixed-layer depth (MLD) definitions, one based on potential density and the other on turbocline (de Boyer Montegut et al., 2004), provided similar results. Large winter MLDs occur over the western portion of the Malvinas Plateau reaching $300 \mathrm{~m}$ in August on average over 25 years (Figure 8a) and maximum values of $600 \mathrm{~m}$ (Figure 8b). Winter mixing convection contributes to the regular outcropping of $27 \mathrm{~kg} / \mathrm{m}^{3}$ and $27.1 \mathrm{~kg} / \mathrm{m}^{3}$ isopycnals over the Malvinas Plateau (Figure 8c). During some winters, water as dense as $27.10 \mathrm{~kg} / \mathrm{m}^{3}$ is found at the surface as north as $44^{\circ} \mathrm{S}$. The maps of potential density maxima at the surface from GLORYS 12 are consistent with maps of 27.10 and $27.20 \mathrm{~kg} / \mathrm{m}^{3}$ isopycnal depths constructed from winter data collected in 1980 (Piola and Gordon, 1989).

The winter MLD and surface potential density over the Malvinas Plateau undergo large interannual variations as illustrated at $51^{\circ} \mathrm{S}$ over the $1500 \mathrm{~m}$ isobath (Figure 8e). Although the MLD time series mimics the surface potential density time series, the deepest MLD do not always correspond to the largest surface density values as other processes contribute to modify density in winter (e.g., eddy mixing, lateral fluxes). The potential density and MLD time series suggest a low frequency modulation (e.g. deep MLD observed in 95-97, 00-02 and 11-12) (Figure 8e). August 2011 registered the deepest (500 m) MLD of the time series. Contrasted synoptic situations in January and August 2011 (Figure 9) along section $51^{\circ} \mathrm{S}$ illustrate processes at stake on the Plateau and are compared to the mean (Figure 6).

\subsection{Modification of water properties on the Malvinas Plateau}

Synoptic Sea Surface Height maps (Figure 9a and f) show an exacerbated mesoscale field compared to the rather smoothed mean field (Figure 6j). The Frontal Zone region (between the SAF-M and PF-N), which corresponds to the large deep reaching velocity std values (Figure 
$6 \mathrm{~h})$, is filled with energetic eddies and meanders leading to active stirring of properties. Indeed, the temperature and salinity fields in the Frontal Zone are drastically different from the smooth means (Figure 9b, c, g and h to be compared with 6a and b) with intrusions of cold and fresh water in the upper $500 \mathrm{~m}$. For example, the $34.05 \mathrm{psu}$ isohaline that is confined near the surface in the mean field deepens down to $450 \mathrm{~m}\left(\mathrm{~km} 450\right.$ in Figure $9 \mathrm{~b}$ ) while the $3^{\circ} \mathrm{C}$ isotherm rises by $700 \mathrm{~m}$ in January (between $\mathrm{km} 200$ and 400 in Figure 9c), which is consistent with the large std values (Figure 6e and f). The spectacular change in the $\Theta-S$ diagram between January and August (Figure 9e and j) reflects the winter convection that reaches the $27.1 \mathrm{~kg} / \mathrm{m}^{3} \sigma_{\theta}$-horizon ventilating the AAIW-U. Indeed, the MLD changes from ten meters in January (strong summer thermocline) to over $500 \mathrm{~m}$ in August in the SAF region.

Selected $\Theta-S$ profiles in January show two changes in the slope of the $\Theta-S$ distribution between the 27.0 and $27.1 \mathrm{~kg} / \mathrm{m}^{3}$ isopycnals (e.g., green profile in Figure 9e). They illustrate the lateral exchanges in the Frontal Zone where the cool and fresh waters from the PF encounter the warmer and salty waters from the west of the SAF. In August the change in slope in the $\Theta-S$ distribution located on the $27.15 \mathrm{~kg} / \mathrm{m}^{3} \sigma_{\theta}$-horizon is associated to a profile within a meander of the PF (red profile in Figure 9j). These polar waters will eventually contribute to the freshening and cooling in the Frontal Zone in the upper $500 \mathrm{~m}$ and the change in slope will migrate to a lighter horizon (as seen in January).

\section{MUW volume transports}

MUW volume transports at each time step were estimated using $\Theta / S$ criteria in the range defined in Figure 6i $\left(\Theta>\Theta_{0}\right.$ and 33.9 $<\mathrm{S}<\mathrm{S}_{0}$ with $\Theta_{0}$ varying between 2.5 and $2.7^{\circ} \mathrm{C}$ and $\mathrm{S}_{0}$ between 34.25 and 34.32). Sensitivities to the temperature and salinity criteria, to the length of the sections were carefully examined using different $\Theta / S$ thresholds, extending sections towards the east and, considering positive only $(\mathrm{T}+)$ and all velocities $(\mathrm{T}+-)$ (see supplementary 
material S6). We also checked the impact of trends in water properties. Indeed, over the slope south of $40^{\circ} \mathrm{S}$ and Malvinas Plateau, rather large freshening trends (with values $0.1,0.08$ and $0.04 \mathrm{psu} /$ decade at 50, 155 and $541 \mathrm{~m}$ respectively) lead to density decreases of about 0.05 $\mathrm{kg} / \mathrm{m}^{3} /$ decade while temperature trends are small (supplementary material S6). However, the 34.25/34.32 psu isohalines remained roughly at the same place (slightly deepening and larger vertical salinity gradient) and therefore the bottom limit of the MUW did not change much. The results were robust, yielded highly correlated transport times series $(r>0.7)$, means within a range of $6 \mathrm{~Sv}$ and stds within a range of $3 \mathrm{~Sv}$. The relative uncertainty of the mean transport was of the order of $16 \%$ for (T+-) (means within a $6 \mathrm{~Sv}$ range) and reduced to $5 \%$ (means within a $1.5 \mathrm{~Sv}$ range) for $(\mathrm{T}+)$. Hereafter we discuss MUW transport computed from positive velocities in the layer defined by $\Theta>2.5^{\circ} \mathrm{C}$ and $33.9<\mathrm{S}<34.25 \mathrm{psu}$. The MUW transport time series ( $\mathrm{T}+)$ and $(\mathrm{T}+-)$ are shown in supplementary material (S5) and their statistics summarized in Table 3.

\subsection{The Malvinas Upper Water transport}

398 The northward MUW transport means decrease towards the north from $31 \mathrm{~Sv}$ at $51^{\circ} \mathrm{S}$ to $27 \mathrm{~Sv}$ at $41^{\circ} \mathrm{S}$ indicating offshore leakage and mixing (Figure $10 \mathrm{a}$ ). The transport std decreases from 4.6 Sv at $51^{\circ} \mathrm{S}$ to $3.4 \mathrm{~Sv}$ at $44^{\circ} \mathrm{S}$ and shows larger values at $41^{\circ} \mathrm{S}$ near the Confluence (5 Sv) and at $59^{\circ} \mathrm{W}(5 \mathrm{~Sv})$ near the blocking region (Figure $2 \mathrm{~b}$ ) where the offshore side of the sections reaches a large EKE region (Figure 1c). MUW transport time series (daily resolution) from different latitudes are significantly correlated and maximum correlations between sections are

404 obtained at small lags ( $<5$ days) (Table 2). The smallest correlations are found with the $41^{\circ} \mathrm{S}$, $40559^{\circ} \mathrm{W}$ and $51^{\circ} \mathrm{S}$ sections which receive perturbations from the Confluence, from 406 blocking/feeding events and, from Drake Passage, respectively (Figure 2) locally affecting the 
transport. Correlations between MUW transport time series at different latitudes are larger

408 (>0.2) than those obtained for the upper $900 \mathrm{~m}$ transport time series (Table 2).

409 The five MUW transport time series do not exhibit much variation at the seasonal time scale

410 (small increase of $2 \mathrm{~Sv}$ in winter in all sections, Figure $10 \mathrm{~b}$ ) and no long-term trend. Annual

411 means vary over a range of about 6 Sv. The annual means show a decrease in 2004 in the five

412 sections (from 3 to $7 \mathrm{~Sv}$ ). The 2004 transport minimum is examined below.

\section{$413 \quad 5.2$ Comparison to upper $900 \mathrm{~m}$ transport}

414 We compared the MUW transport (integrated in the layer defined by $\Theta>2.5^{\circ} \mathrm{C}$ and $41533.9<\mathrm{S}<34.25 \mathrm{psu})$ at $44^{\circ} \mathrm{S}$ and $47^{\circ} \mathrm{S}$ to the MC transport without water mass distinction, 416 integrated in the first $900 \mathrm{~m}$ (Figure 11a and b). The std and mean transport considering the 417 first $900 \mathrm{~m}$ is larger than the MUW transport (mean of 37 and $42 \mathrm{~Sv}$ and stds of 4 and $4.8 \mathrm{~Sv}$ 418 at $44.7^{\circ} \mathrm{S}$ and $47^{\circ} \mathrm{S}$ respectively).

419 The MUW and the $900 \mathrm{~m}$ volume transport time series are correlated $(\mathrm{r}>0.8$ above the $99 \%$ 420 confidence level). However, at specific events they show an opposite behavior with the $900 \mathrm{~m}$ transport experiencing an increase and the MUW transport a drastic decrease (e.g., year 1995, 2004 end of 2011 in Figure 11a and b). The dates of large difference correspond to feedings events of the MC when Polar waters are supplied to the offshore side of the MC as the PF-N meanders northward (Figure 2b, Figure 11c and d, Artana et al., 2018c). Indeed, polar waters are not considered in the MUW transport computation leading to a decrease in the MUW transport while the PF-N cyclonic meander of the PF-N tends to accelerate the offshore MC flow leading to an increase in the $900 \mathrm{~m}$ transport. The transport differences are larger during years 93-97 and 04-17 in agreement with increased occurrence of feeding events during these periods (Figure 11c and d). In contrast, transport differences reduce during blocking events 
(Figure 2b) as the anticyclonic anomalies obstructing the $\mathrm{MC}$ flow at $49^{\circ} \mathrm{S}$ carry warm and salty waters that are not included in the MUW transport computation (Figure 11c and d).

Year 2004 stands out with prolonged feeding events and two blocking events in March and October (Figure $11 \mathrm{c}$ and d). The feeding and blocking events lasted 30 days and 40 days and were associated with density anomalies of $+0.08 \mathrm{~kg} / \mathrm{m}^{3}$ and $-0.13 \mathrm{~kg} / \mathrm{m}^{3}$, respectively. This year corresponds to a notable decrease in the MUW annual mean transports at all latitudes (Figure 10c) while the $900 \mathrm{~m}$ annual mean transport is $0.5 \mathrm{~Sv}$ larger than the mean (not shown). In year 2004 the South Atlantic Subtropical High was located to the southwest of its mean location (Figure 12a) and a large southward intrusion of salty and warm subtropical waters into the Argentine Basin occurred (Figure 12b). As a result, salinity increased by more than 0.2 psu at the surface and $0.1 \mathrm{psu}$ at $541 \mathrm{~m}$ in the western Argentine Basin (Figure $12 \mathrm{c}$ and e). In particular, waters saltier than 34.25 psu reached the offshore side of the northern sections $\left(41^{\circ} \mathrm{S}\right.$, $44^{\circ} \mathrm{S}$ and $47^{\circ} \mathrm{S}$ ) on several occasions (Figure 12d) and, in March and October generated two blocking events on the $59^{\circ} \mathrm{W}$ section (not shown).

444 All over the Patagonian slope waters were $0.1 \mathrm{psu}$ fresher at the surface and 0.1 saltier at 541 $\mathrm{m}$ as a result of the prolonged feeding events (Figure $12 \mathrm{~b}-\mathrm{e}$ ). The salty (>34.25 psu) waters

446 from the blocking and feeding (delimited with red in Figure 12b and d) events are excluded 447 from the computation of the MUW transport, explaining the decrease in the annual means in 4482004 (Figure 10c). 


\section{Summary and discussion:}

455 This work builds upon previous works that assessed GLORYS12 skills in the upper layer in 456 the Southwestern Atlantic Ocean. We used 25 years of GLORYS12 ocean reanalysis to revisit 457 the upper Malvinas Current along its path from Drake Passage to the Brazil-Malvinas 458 Confluence from synoptic to interannual time scales. In the upper $900 \mathrm{~m}$, the MC carries 459 Subantarctic Surface Waters and Antarctic Intermediate Water (we called them, Malvinas 460 Upper Waters, MUW) and some Upper Circumpolar Deep Waters.

461 The MC is a rather steady current connecting two regions with high eddy kinetic energy (Drake Passage and the Brazil-Malvinas Confluence) as most of the EKE leaking from Drake Passage is damped over the Malvinas Plateau. Indeed, The Malvinas Plateau is a hotspot region for 464 eddy activity dissipation (Artana et al., 2016, Figure 2a), and for local water mass properties modification either through eddy mixing or through winter convection (Figure 13 a). On the Malvinas Plateau, deep winter mixed layers attain on average a depth of $300 \mathrm{~m}$ and occasionally reach $600 \mathrm{~m}$. Deep mixed layers reach density values as large as $27.1 \mathrm{~kg} / \mathrm{m}^{3}$, ventilating the AAIW-U as observed in Piola and Gordon (1989).

The upper $900 \mathrm{~m}$ transport mean decreases from $40 \mathrm{~Sv}$ at $51^{\circ} \mathrm{S}$ to $35 \mathrm{~Sv}$ at $41^{\circ} \mathrm{S}$ indicating offshore leakage along the MC path. At $51^{\circ} \mathrm{S}$ the upper MC volume transport (40 Sv) receives a mean contribution of $3 \mathrm{~Sv}$ from $\mathrm{WBB}, 23 \mathrm{~Sv}$ from EBB and $14 \mathrm{~Sv}$ from SRP.

Computing MC transport time series at different latitudes requires care because the choice of the eastern limit of the section, embedded in large EKE regions, impacts on the transport time

474 series variations. Transport time series in the upper $900 \mathrm{~m}$ and in the MUW layer were 475 produced considering positive $(\mathrm{T}+)$ and both sign velocities $(\mathrm{T}+-)$ to take into account the 476 difficulties associated with the open eastern boundary. The mean MUW transport is not very sensitive to the different $\Theta / S$ criteria used (in the range defined by $\Theta>\Theta_{0}$ and $33.9<S<S_{0}$ with $\Theta_{0}$ varying between 34.25 and 34.32 ) while the relative uncertainty reduces from $16 \%$ in MUW 
479 (T+-) to 5\% in the MUW (T+). The $900 \mathrm{~m}$ volume transport and the MUW transport are 480 correlated $(>0.8)$ and show little seasonality (relative seasonal std of $2 \%$ ) and no trend.

481 Differences between the upper $900 \mathrm{~m}$ transport and the MUW transport are modulated by the 482 occurrence of feeding events and blocking events. Indeed, waters advected during blocking 483 events (salty and warm in the upper layer) and feeding events (fresh at the surface and salty at 484 depth) are excluded from the computation of the MUW transport. The 2004 MUW transport 485 minimum (reduction of $5 \mathrm{~Sv}$ ) was associated with a unique southward displacement of the BC overshoot, blocking events at $48^{\circ} \mathrm{S}$ and a prolonged feeding event. Synoptic transport maxima in the upper $900 \mathrm{~m}$ are associated either to feeding events in the

488 South or cyclonic eddies propagating north or local mesoscale activity at the Confluence 489 (Figure 13b). As cyclones with polar water do not contribute to the MUW transport, the MUW 490 maxima are not necessarily simultaneous with the upper $900 \mathrm{~m}$ transport maxima (Figure 13b). Drastic reductions in the upper $900 \mathrm{~m}$ and MUW transport occurred at the Confluence and at $59^{\circ} \mathrm{W}$ during blocking events (Figure 13c). Over the 25 years, 100 blocking events and 96 493 feeding events occurred at $59^{\circ} \mathrm{W}$. Blocking events at $59^{\circ} \mathrm{W}$ became more frequent over the last 494 decade (35 during 93-05 and 65 during 05-17). The southward displacement of the BC 495 overshoot could contribute to that increase (Figure 13c). However, the origin of the perturbations leading to the blocking events remains uncertain. Backward trajectories of lagrangian particles did not lead to conclusive results: tracking back anomalies in the Argentine

498 Basin is difficult because of the intense mesoscale activity. It is possible that events of transport 499 reductions as the one in 2004 will be more frequent in the future.

500 Overall the MC is a strong and steady current. The standard deviation of the transport is small relative to the mean: about $10 \%$ at $44.7^{\circ} \mathrm{S}$ and $47^{\circ} \mathrm{S}$ and $20 \%$ at $41^{\circ} \mathrm{S}$ near the Confluence, $59^{\circ} \mathrm{W}$ in the blocking region and $51^{\circ} \mathrm{S}$ on the Malvinas Plateau. In contrast, the ratio std/mean 503 of the $\mathrm{BC}$ transport is of the order of $57 \%$ at $37^{\circ} \mathrm{S}$ (Artana et al., 2019 a). The MC plays a minor 
504 role in the velocity variations observed at the confluence at seasonal and interannual scales.

505 Velocity trends are small over the MC while they are large at the Brazil Malvinas Confluence

506 and the overshoot $(10 \mathrm{~cm} / \mathrm{s} /$ decade at the surface $)$ as the $\mathrm{BC}$ migrated southward over the last

50725 years.

508 Estimates of total volume transport provide values (70 to $45 \mathrm{~Sv}$ from south to north) that are in 509 agreement with the few existing estimates based on observations (Peterson, 1992; Saunders 510 and King, 1995: Maamaatuaiahutapu et al., 1998; Colin de Verdière and Ollitrault, 2016). Deep

511 Argo floats deployed in the Southern Ocean will be examined to precisely evaluate the water

512 mass characteristics and velocities at depths in GLORYS12. Furthermore, on-going efforts aim

513 at providing a new ocean reanalysis with the number of vertical levels increasing from 50 to

51475 and assimilating deep Argo floats. These improvements will probably provide further 515 insights on deep circulation and water masses.

516 Acknowledgments:

517 We are grateful to the CNES (Centre National d'Etudes Spatiales) for constant support.

518 This study is a contribution to EUMETSAT/CNES DSP/OT/12-2118. Léa Poli

519 acknowledges support from Sorbonne Université and Camila Artana from a CNES Postdoc

520 Scholarship. The model outputs are available at Copernicus Marine Environment

521 Monitoring Service (CMEMS; http://marine.copernicus.eu/).

522

523

524

525

526

527 
530

531

532

533

534

535

536

537

538

539

540

541

542

543

544

545

546

547

548

549

550

551

552

553

554

555

556

557

558

559

560

561

562

563

564

565

566

567

568

569

570

571
Artana, C., Ferrari, R., Koenig, Z., Saraceno, M., Piola, A., \& Provost, C. (2016). Malvinas Current variability from Argo floats and satellite altimetry. Journal of Geophysical Research: Oceans, 121, 4854-4872, https://doi.org/10.1002/2016JC011889

Artana, C., Ferrari, R., Koenig, Z., Sennéchael, N., Saraceno, M., Piola, A. R., \& Provost, C. (2018). Malvinas Current volume transport at $41^{\circ} \mathrm{S}$ : A 24-year long time series consistent with mooring data from 3 decades and satellite altimetry. Journal of Geophysical Research:Oceans, https://doi.org/10.1002/2017JC013600

Artana, C., Lellouche, J. M., Park, Y. H., Garric, G., Koenig, Z., Sennéchael, N., et al. (2018). Fronts of the Malvinas Current System: surface and subsurface expressions revealed by satellite altimetry, Argo floats, and Mercator operational model outputs. Journal of Geophysical Research: Oceans, https://doi.org/10.1029/2018JC013887

Artana, C., Lellouche, J.-M., Sennéchael, N., \& Provost, C. (2018). The open-ocean side of the Malvinas Current in Argo float data and 25 years of reanalyses from Mercator operational system. Journal of Geophysical Research: Oceans, 123, 8489-8507, https://doi.org/10.1029/ 2018JC014528.

Artana, C., Provost, C., Lellouche, J.-M., Rio, M.-H., Ferrari, R., \& Sennéchael, N. (2019). The Malvinas Current at the Confluence with the Brazil Current: Inferences from 25 years of Mercator Ocean reanalysis. Journal of Geophysical Research: Oceans, 124, https://doi.org/10.1029/2019JC015289

Artana, C., Ferrari, R., Bricaud, C., Lellouche, J.-M., Garric, G., Sennéchael, N., Lee, J-H., Park, Y.-H. \& Provost, C. (2019). Twenty-five years of Mercator ocean reanalysis GLORYS12 at Drake Passage: velocity assessment and total volume transport. Journal of Advances in Space Research, https://doi.org/10.1016/j.asr.2019.11.033

Barré, N., Provost, C., \& Saraceno, M. (2006). Spatial and temporal scales of the BrazilMalvinas Confluence documented by simultaneous MODIS Aqua 1.1-km resolution SST and color images. Journal of Advances in Space Research, 37(4), 770786,https://doi.org/10.1016/j.asr.2005.09.026

Böning, C. W., Dispert, A., Visbeck, M., Rintoul, S. R., \& Schwarzkopf, F. U. (2008). The response of the Antarctic Circumpolar Current to recent climate change. Nature Geoscience, 1(12), 864-869, https://doi.org/10.1038/ngeo362

Boyer Montegut, C., G. Madec, A. S. Fischer, A. Lazar, \& D. Iudicone (2004). Mixed layer depth over the global ocean: An examination of profile data and a profile-based climatology, Journal of Geophysical Research, 109, C12003, https://doi.org/10.1029/2004JC002378. 
573 Cabanes, C., Grouazel, A., Schuckmann, K. V., Hamon, M., Turpin, V., Coatanoan, C., et al.

574 (2013). The CORA dataset: Validation and diagnostics of in-situ ocean temperature and salinity measurements. Ocean Science, 9(1), 1-18, https://doi.org/10.5194/os-9-1-2013

Close, S. E., Garabato, A. C. N., Mcdonagh, E. L., King, B. A., Biuw, M., \& Boehme, L. (2013). Control of mode and intermediate water mass properties in Drake passage by the Amundsen sea low. Journal of Climate, 26(14), 5102-5123, https://doi.org/10.1175/JCLI-D$\underline{18-0205.1}$

581

Colin de Verdière, A., and M.Ollitrault, 2016: Direct determination of the world ocean

barotropic circulation. Journal of Physical Oceanography , 46, 255-273, https://doi:10.1175/JPO-D-15-0046.1.

Frey, D. I., Piola, A. R., Krechik, V. A., Fofanov, D. V., Morozov, E. G., Silvestrova, K. P., et al. (2021). Direct measurements of the Malvinas Current velocity structure. Journal of Geophysical Research: Oceans, 126, e2020JC016727. https://doi.org/10.1029/2020JC016727

589 Gordon, A. L., \& C. L. Greengrove (1986). Geostrophic circulation of the Brazil-Falkland 590 Confluence, Deep Sea Research, Part A, 33, 573 - 585, https://doi.org/:10.1016/0198$591 \quad 0149(86) 90054-3$

592 Gordon, A. L., Weiss, R., Smethie, W., \& Warner, M. (1992). Thermocline and intermediate 593 water communication between the South Atlantic and Indian Oceans. Journal of Geophysical Research, 97, 7223-7240, https://doi.org/10.1029/92JC00485

Lellouche, J.-M., Greiner, E., Le Galloudec, O., Garric, G., Regnier, C., Drevillon, M., et al. (2018). Recent updates on the Copernicus Marine Service global ocean monitoring and forecasting real-time $1 / 12^{\circ}$ high resolution system. Ocean Science Discussions. https://doi.org/10.5194/os-2018-15

Lellouche, J.-M., Le Galloudec, O., Drevillon, M., Regnier, C., Greiner, E., Garric, G., et al. (2013). Evaluation of real time and future global monitoring and forecasting systems at Mercator Ocean. Ocean Science Discussions, 9, 1123-1185, https://doi.org/10.5194/osd-91123-2012 Spring and winter water mass composition in the Brazil-Malvinas Confluence. Journal of Marine Research, 52, 397-426, https://doi.org/10.1357/0022240943077064 and Malvinas Currents at their confluence, Journal of Marine Research, 56, 417-438, https://doi.org/10.1357/002224098321822366 
618 Naveira Garabato, A. C., Jullion, L., Stevens, D. P., Heywood, K. J., \& King, B. A. (2009).

619 Variability of subantarctic mode water and Antarctic Intermediate Water in the Drake Passage

620 during the late-twentieth and early-twenty-first centuries. Journal of Climate, 22(13),

621

622

623 Paniagua, G., Saraceno, M., Piola, A., Provost, C., Guerrero, R., Ferrari, R., et al. (2018).

624 Dynamics of the Malvinas Current at $41^{\circ} \mathrm{S}$ : First assessment of temperature and salinity

625 temporal variability. Journal of Geophysical Research: Oceans, https://doi.org/10.1029/

626 2017JC013666

627 Peterson, R. G., \& Whitworth, T. (1989). The subantarctic and polar fronts in relation to deep 628 water masses through the southwestern Atlantic. Journal of Geophysical Research, 94(C8), 629 10,817-10,838, https://doi.org/10.1029/JC094iC08p10817

630 Peterson, R. G. (1992), The boundary currents in the western Argentine Basin, Deep Sea 631 Research. Part A, 39(3-4), 623-644. https://doi.org/10.1016/0198-0149(92)90092-8

632

Piola A. \& Gordon A.L. (1989). Intermediate waters in the southwest South Atlantic. Deep-

634

635

636 Piola, A. R., Franco, B. C., Palma, E. D., \& Saraceno, M. (2013). Multiple jets in the Malvinas

637 Current. Journal of Geophysical Research: Oceans, 118, 2107-2117, 638 https://doi.org/10.1002/jgrc.20170

639

640 Poli, L., Artana, C., Provost, C., Sirven,J., Sennéchael, N., Cuypers, Y., \& Lellouche, J.-M. 641 (2020). Anatomy of subinertial waves along the Patagonian shelf break in a $1 / 12^{\circ}$ global 642 operational model. Journal of Geophysical Research: Oceans, 125, e2020JC016549, https:// 643 doi.org/10.1029/2020JC016549

644

645 Provost, C., Gana, S., Garçon, V., Maamaatuaiahutapu, K., \& England, M. (1995). 646 Hydrographic conditions during austral summer 1990 in the Brazil/Malvinas Confluence 647 region. Journal of Geophysical Research, 100(C6), 10655-10682, 648 https://doi.org/10.1029/94JC02864

649

650 Pujol, M.-I., Faugère, Y., Taburet, G., Dupuy, S., Pelloquin, C., Ablain, M., \& Picot, N. (2016). 651 DUACS DT2014: The new multi-mission altimeter data set reprocessed over 20 years. Ocean 652 Science, 12(5), 1067-1090., https://doi.org/10.5194/os-12-1067-2016

653

654 Purich, A., England, M. H., Cai, W., Sullivan, A., \& Durack, P. J. (2018). Impacts of broad655 scale surface freshening of the Southern Ocean in a coupled climate model. Journal of Climate, 656

658 Romero, S. I., Piola, A. R., Charo, M., \& Garcia, C. A. E. (2006). Chlorophyll-a variability off 659 Patagonia based on SeaWiFS data. Journal Geophysical Research, 111, C05021. 660 https://doi.org/10.1029/2005JC003244 
661 Saraceno M., Provost C., Piola A., Guerrero R., Ferrari R., Paniagua G. F., Lago L. S., \&

662 Artana C. (2020). Malvinas Current 2015-2017: Mooring velocities. SEANOE,

663 https://doi.org/10.17882/76617

664

665 Saunders, P. M. \& B. A. King. (1995). Bottom currents derived from a shipborneADCP on

666 WOCE cruiseA11 in the South Atlantic. Journal of Physical Oceanography, 25, 329-347,

667 https://doi.org/10.1175/1520-0485(1995)025.

668

669 Smith, W. H. F., \& Sandwell, D. T. (1994). Bathymetric prediction from dense satellite

670 altimetry and sparse shipboard bathymetry. Journal of Geophysical Research, 99, 21 803-21

671 824. https://doi.org/10.1029/94JB00988

672

673 Spadone, A., \& Provost, C. (2009). Variations in the Malvinas Current volume transport since

674 October 1992. Journal of Geophysical Research, 114, C02002,

675 https://doi.org/10.1029/2008JC004882

676

677 Szekeley, T., Gourrion, J., Pouliquen, S., \& Reverdin, G. (2016). CORA, Coriolis, Ocean

678 Dataset for Reanalysis. SEANOE, https://doi.org/10.1029/2008JC05248

679

680 Valla, D., \& Piola, A. R. (2015). Evidence of upwelling events at the northern Patagonian shelf

681 break. Journal of Geophysical Research: Oceans, 120, 7635-7656.

682 https://doi.org/10.1002/2015JC011002

683

684 Vivier, F., \& Provost, C. (1999a). Direct velocity measurements in the Malvinas Current.

685 Journal of Geophysical Research, 104, 21083-21104. https://doi.org/10.1029/1999JC900163

686

687 Vivier, F., \& Provost, C. (1999b). Volume transport of the Malvinas Current: Can the flow be

688 monitored by TOPEX/Poseidon? Journal of Geophysical Research, 104, 21105-21122.

689 https://doi.org/10.1029/1999JC900056

690

691

692

693

694

695

696

697

698

699

700

701

702

703

704 
Figure 1: a) Bottom topography of the Southwestern Atlantic and Drake Passage (in meters) from Smith and Sandwell (1994). The main passages through North Scotia Ridge are indicated: West of Burwood Bank (WBB), East of Burwood Bank (EBB), and Shag Rocks Passage (SRP). The mean location of the Antarctic Circumpolar Current fronts is schematized: Subantarctic

710 Front (SAF-N and SAF-M, blue dashed and solid lines), Polar Front (PF-N and PF-M in yellow solid and dashed lines), and Southern ACC Front (SACFF, in green). The mean position of the Brazil Current Front (BCF) is indicated in red. b) mean surface velocities from 1993 to 2017 (in $\mathrm{cm} / \mathrm{s}$ ) from the ocean reanalysis (GLORYS12) documented in this study. c) Square root of 714 eddy kinetic energy over 25 years (in cm/s) from GLROYS12. In b and c the 300, 500 and $7151500 \mathrm{~m}$ isobaths are indicated with thick black contours and the $6,000,5,000,3,000,2,000$ with gray contours. Five sections crossing the $\mathrm{MC}$ at $41^{\circ} \mathrm{S}$ (red), $44.7^{\circ} \mathrm{S}$ (blue), $47^{\circ} \mathrm{S}$ (orange), $59^{\circ} \mathrm{W}$ (green) and $51^{\circ} \mathrm{S}$ (purple) and three sections at North Scotia Ridge, WBB, EBB and SRP (magenta) are indicated.

Figure 2: Schematics of physical processes in the MC based on previous studies. a) Grey shading represents dissipation over the Malvinas Pateau of the mesoscale activity leaking through North Scotia Ridge (Artana et al., 2016). Trapped waves (locally wind forced and remotely forced) propagating along the Patagonian slope are schematized in blue (Poli et al., 2020). b) Blocking events in red: anticyclonic anomalies cut the MC from the Antarctic Circumpolar Current at $49^{\circ} \mathrm{S}$; the MC does not collapse as a recirculation cell is established (Artana et al., 2016 and 2018c). Feeding events in blue: waters from the South of the Polar Front are injected into the MC and recirculate between the MC and Malvinas Return Flow (Artana et al., 2018c). c) Maxima and minima of the MC transport at $41^{\circ} \mathrm{S}$ are associated with eddies coming from the Argentine Basin: Transport maximum cases (in blue) are associated 
with cyclonic eddies detached from the PF and transport minimum cases (in red) with southward displacement of the Subantarctic Front due to large anticyclonic anomalies from the Brazil Current (Artana et al., 2018a).

733

734 Figure 3: a) Bathymetry gradient $(\mathrm{m} / \mathrm{km})$. Dashed lines indicate the 300, 500 and $1500 \mathrm{~m}$ isobaths. (b) Mean along-slope surface velocities in $\mathrm{cm} / \mathrm{s}$ along five sections crossing the MC at $41^{\circ} \mathrm{S}$ (red), $44.7^{\circ} \mathrm{S}$ (blue), $47^{\circ} \mathrm{S}$ (orange), $59^{\circ} \mathrm{W}$ (green) and $51^{\circ} \mathrm{S}$ (purple) (indicated in a). Shaded areas correspond to the velocity std . X-axis is distance in $\mathrm{km}$ from isobath $100 \mathrm{~m}$. (c) Bathymetry along the same sections (same color code). Y-axis is depth in meters. Solid and dashed vertical lines indicate the location of maximum velocities of the offshore (SAF-M) and inshore (SAF-N) jets.

741

742 Figure 4: Surface velocity anomalies over 25 years (in cm/s) in February (a) and August (b).

743 The mean position of the Subantarctic Front (Sea Surface Height $=-5 \mathrm{~cm}$ ) and Brazil Current

744 Front ( Sea Surface Height=30 cm) are indicated in black contours. c-d) Significant linear 745 trends (above the $95 \%$ confidence level) in surface velocity (cm/s/decade) and EKE $746\left(\mathrm{~cm}^{2} / \mathrm{s}^{2} /\right.$ decade $)$ computed over 25 years $(1993-2017)$. The black contour delineates points 747 where the 25-year trend is larger than the std. Isobaths as in figure 2. Five sections crossing the $\mathrm{MC}$ at $41^{\circ} \mathrm{S}$ (red), $44^{\circ} \mathrm{S}$ (blue), $47^{\circ} \mathrm{S}$ (orange), $59^{\circ} \mathrm{W}$ (green) and $51^{\circ} \mathrm{S}$ (purple) three sections

749 at North Scotia Ridge (in magenta) are indicated.

750

751 Figure 5: Mean transport stream functions computed between surface and $900 \mathrm{~m}$ depth over 25 years (a), over the 25 months of February (b) and August (c), over full year 2015 (d) and

753 full year 2003 (e). Streamlines are plotted every 5 Sv. Background is mean volume transport 754 (in Sv) in each model grid (transport density). Five sections crossing the $\mathrm{MC}$ at $41^{\circ} \mathrm{S}$ (red), 
$44^{\circ} \mathrm{S}$ (blue), $47^{\circ} \mathrm{S}$ (orange), $59^{\circ} \mathrm{W}$ (green) and $51^{\circ} \mathrm{S}$ (purple) and three sections at North Scotia Ridge (in magenta) are indicated.

Figure 6: (a-d) Mean and (e-h) std of potential temperature $\left({ }^{\circ} \mathrm{C}\right)$, salinity (psu), density $\left(\mathrm{kg} / \mathrm{m}^{3}\right)$ and along slope velocities from GLORYS12 (1993-2017) along the Patagonian slope at $51^{\circ} \mathrm{S}$ (purple section in $\mathrm{j}$ ). $\mathrm{X}$-axis in $\mathrm{km}$ from the $100 \mathrm{~m}$ isobath and $\mathrm{Y}$-axis is depth in $\mathrm{m}$. The 2.5 ${ }^{\circ} \mathrm{C}$ isotherm and $34.25 \mathrm{psu}$ isohaline are indicated in red, the $27.00,27.14,27.29,27.35 \mathrm{~kg} / \mathrm{m}^{3}$ isopycnal in dashed white. i) Corresponding mean $\Theta-S$ diagram. The vertical rectangle marks 34.25 and 34.32 psu values and the horizontal rectangle the 2.5 and $2.7^{\circ} \mathrm{C}$ values. j) Mean Sea Surface Height (in $\mathrm{cm}$ ) over 25 years. The SAF-N/SAF-M and PF-N/PF-M are indicated in solid/dashed blue and red lines respectively.

Figure 7: a) Mean thickness (in m) of MUW layer (waters with $\Theta_{\text {mean }}>2.5^{\circ} \mathrm{C}$ and $33.9<\mathrm{S}_{\text {mean }}$ $<34.32 \mathrm{psu}$ ) b) Mean depth (in m) of the upper boundary of the MUW layer c) Presence probability of MUW over upper $900 \mathrm{~m} .100 \%$ means that these waters occupy the whole upper $900 \mathrm{~m}$ all the time. Black solid and dashed contour indicates the position of the Subantarctic Front and Polar Front and the red contour the position of the Subtropical Front.

Figure 8: Mean (a and c) and maximum (b and d) mixed layer depth (in $\mathrm{m}$ ) and surface potential density in August. Grey colors indicate regions where the MLDs reach the bottom e) Mixed layer depth (purple in $\mathrm{m}$ ) and potential density $\left(\mathrm{in} \mathrm{kg} / \mathrm{m}^{3}\right.$ ) time series above the Malvinas Plateau at the blue point indicated in a-c.

Figure 9: a): Sea Surface Height map of 2 January 2011.The position of the SAF-M/SAF-N and PF-N/PF-M are indicated in blue and red. The 500, 1000, 1500, 2000 and $2500 \mathrm{~m}$ isobaths 
are indicated in grey. b,c and d): Salinity, Temperature and along slope velocities over the $51^{\circ} \mathrm{S}$

781

782

783

784

785

786

787

788

789

790

791

792

793

794

795

796

797

798

799

800

801

802 Figure 12: a): Mean Sea Level Pressure contours averaged over 2004 (in red) and over the 25

803 years (in blue). b and d): Mean salinity at the surface and $541 \mathrm{~m}$ over 2004. The cyan and red 804 section indicated in purple in Figure a. The $2.5^{\circ} \mathrm{C}$ and $2.7^{\circ} \mathrm{C}$ isotherms and the $34.32 \mathrm{psu}$ and 34.25 psu isohaline are indicated with dashed red contour. The MLD is indicated with a pink contour. e) $\Theta-S$ diagram from January 2011 over the $51^{\circ} \mathrm{S}$ section indicated in grey in a) The vertical rectangle marks 34.25 and 34.32 psu values and the horizontal rectangle the 2.5 and $2.7^{\circ} \mathrm{C}$ values. In colors selected profiles from 2 January. The location of each profile is indicated with colored diamonds in a (f-j) same for August 2011. The selected profiles are from the 31 August 2011.

Figure 10: a) Stream function of the mean volume transport associated to the MUW layer $(\Theta>2.5$ ${ }^{\circ} \mathrm{C}$ and $33.9<\mathrm{S}<34.25 \mathrm{psu}$ ). Background is mean volume transport in each model grid (in Sv) and isolines are plotted every $5 \mathrm{~Sv}$. Monthly (c) and yearly (c) averages of MUW volume transport (in Sv) along in the MC.

Figure 11: Volume transport time series across the $\mathrm{MC}$ at (a) $44^{\circ} \mathrm{S}$ and (b) $47^{\circ} \mathrm{S}$. Dark-colored timeseries correspond to MUW volume transport and light-colored time series to the volume transport integrated over the upper $900 \mathrm{~m}$. Difference between the two transport time series at $44^{\circ} \mathrm{S}$ in blue (c) and $47^{\circ} \mathrm{S}$ in orange(d). Superimposed in black is the time series of potential density at $541 \mathrm{~m}$ averaged over the yellow box in Figure $12 \mathrm{~d}$. Densities larger than the std in blue indicate feeding while densities lower than the std in red indicate blocking events (Artana et al., 2018c).

\footnotetext{
contour represent the mean position of the 33.9 and 34.25 psu isohalines. c and e): Salinity
} 

anomaly at the surface and $541 \mathrm{~m}$ over 2004. Indicated are five sections along the MC and three sections across North Scotia Ridge and a yellow box in d) over which spatially averaged

807 time series of potential density are computed (shown in Figure $11 \mathrm{c}$ and d).

808

809 Figure 13: Schematics of MC transports and physical processes. a) The mean and std of the 810 upper $900 \mathrm{~m}$ transports $(\mathrm{T}+900 \mathrm{~m})$ and the MUW transports $(\mathrm{T}+\mathrm{MUW})$ are indicated in red 811 and green boxes. The Malvinas Plateau is home to active eddy mixing, eddy dissipation and 812 deep winter mixed layers occasionally reaching $600 \mathrm{~m}$ depth (yellow). b) Synoptic transport 813 maxima correspond either to polar front meanders or to cyclones. c) Synoptic transport minima 814 are associated with anticyclones. The southward migration of the Brazil Current overshoot (red 815 arrow) led to an increase of mesoscale activity south of $44^{\circ} \mathrm{S}$

816

817

818

819

820

821

822

823

824

825

826

827

828

829 
831

832 Table 1: Statistics of the upper $900 \mathrm{~m}$ volume transport computed considering only positive $833(\mathrm{~T}+)$ and all velocities (T+-) velocities across 5 sections crossing the $\mathrm{MC}$ at $41^{\circ} \mathrm{S}, 44^{\circ} \mathrm{S}, 47^{\circ} \mathrm{S}$, $83459^{\circ} \mathrm{W}$ and $51^{\circ} \mathrm{S}$ and 3 sections at North Scotia Ridge : at EBB, WBB and SRP (location 835 indicated in Figure 1c). The correlation coefficient (r) between transport time series computed 836 from $\mathrm{T}+$ and $\mathrm{T}+/$ - is reported in the last column.

837

838 Table 2: Correlations between the transport time series at different latitudes. In each box, the 839 first line corresponds to the volume transport in the upper $900 \mathrm{~m}$, the second line to the MUW 840 volume transport. Both transport time series were computed only considering positive 841 velocities.

842

843 Table 3: statistics for MUW transport computed considering positive $(\mathrm{T}+)$ and both sign 844 velocities (T+-) across 5 sections crossing the $\mathrm{MC}$ at $41^{\circ} \mathrm{S}, 44^{\circ} \mathrm{S}, 47^{\circ} \mathrm{S}, 59^{\circ} \mathrm{W}$ and $51^{\circ} \mathrm{S}$ and 3 845 sections at North Scotia Ridge: at EBB, WBB and SRP (location indicated in Figure 1c). The 846 correlation coefficient $(\mathrm{r}$ ) between transport time series computed from $\mathrm{T}+$ and $\mathrm{T}+/-$ is reported 847 in the last column.

848

849

850

851 


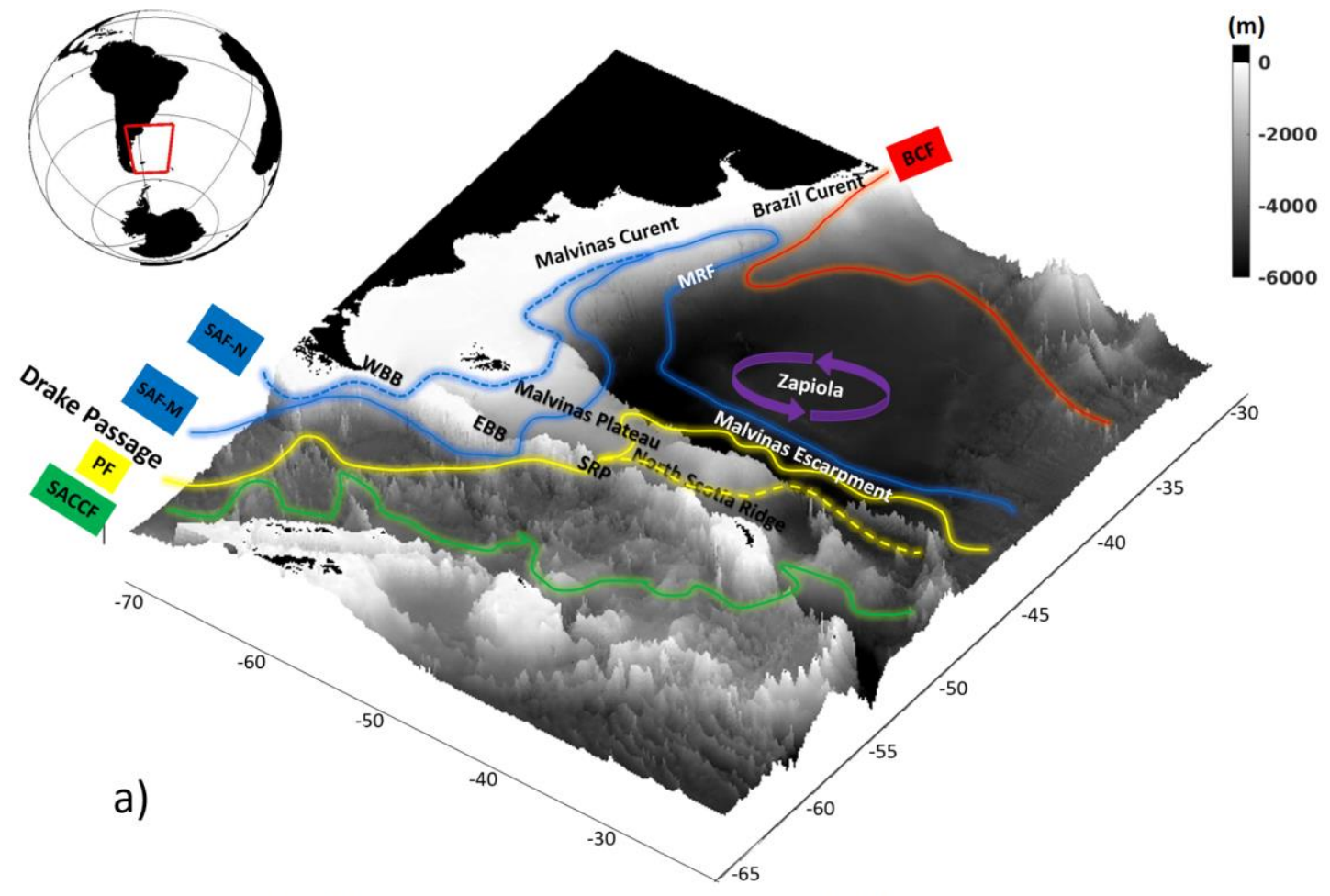

(cm/s)
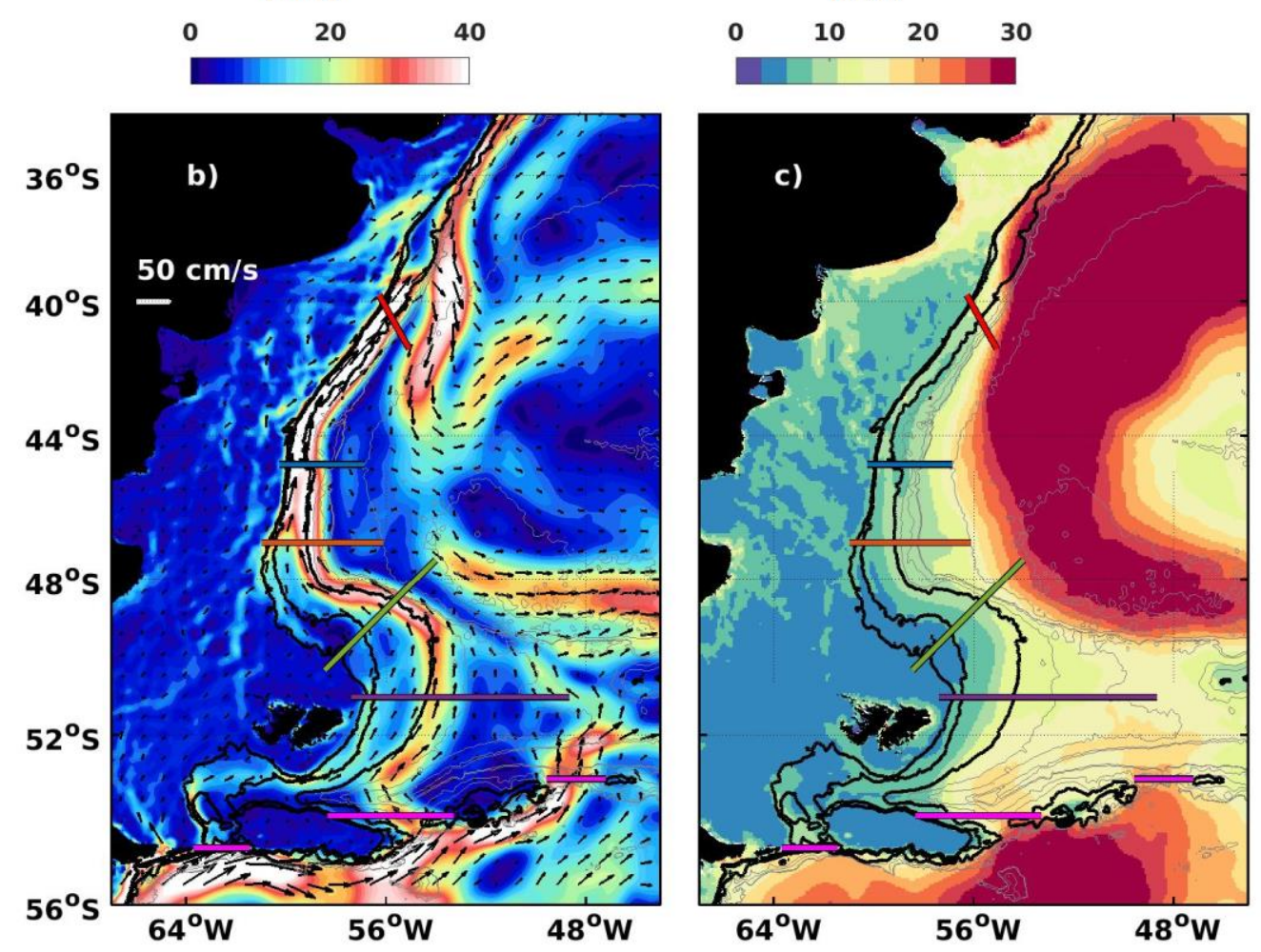

852

853 Figure 1 

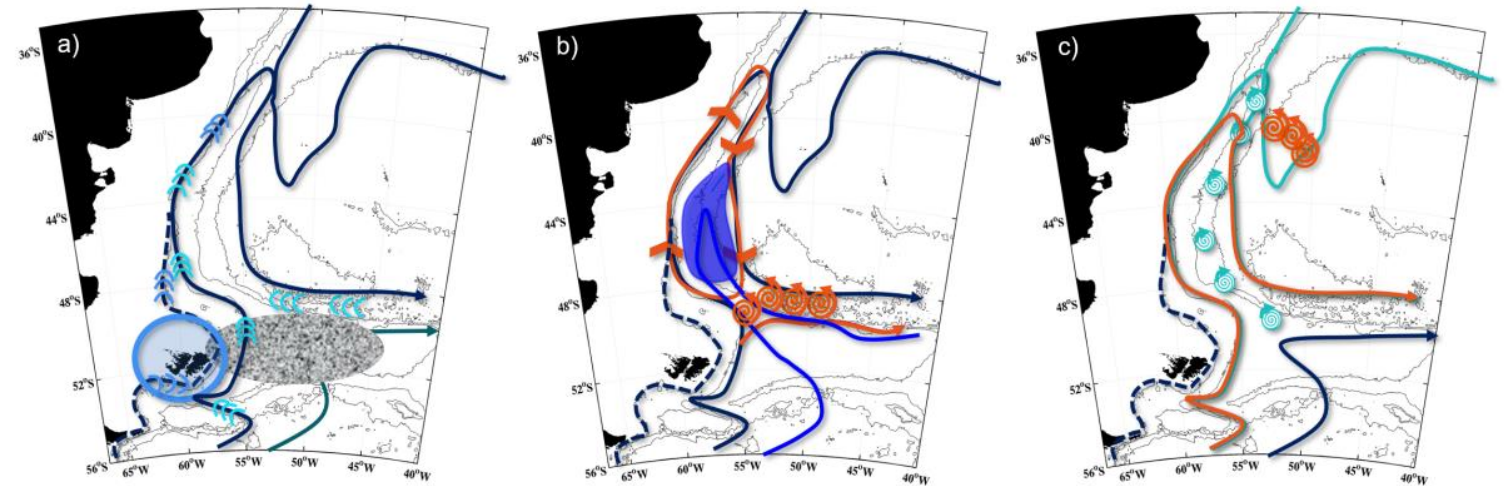

\begin{tabular}{|lll|}
\hline ล & Wissipation & Anticyclones \\
$\mathrm{O}$ & Wind forcing & Cyclones \\
\hline
\end{tabular}

854

855

856

857

858

859

860

861

862

863

864

865

866

867

868

869

870

871

872

873

874 


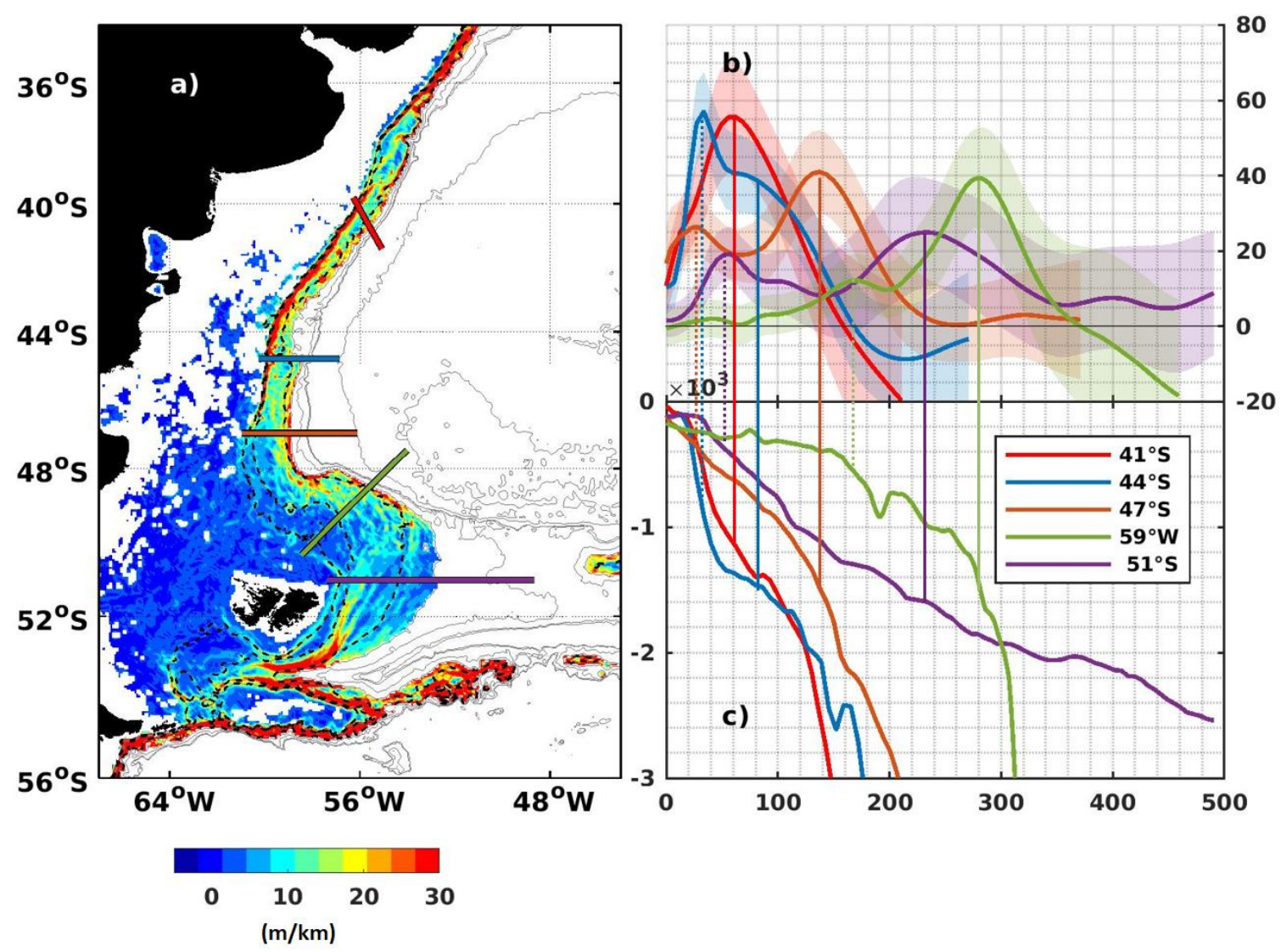

875

876

Figure 3

877

878

879

880

881

882

883

884 

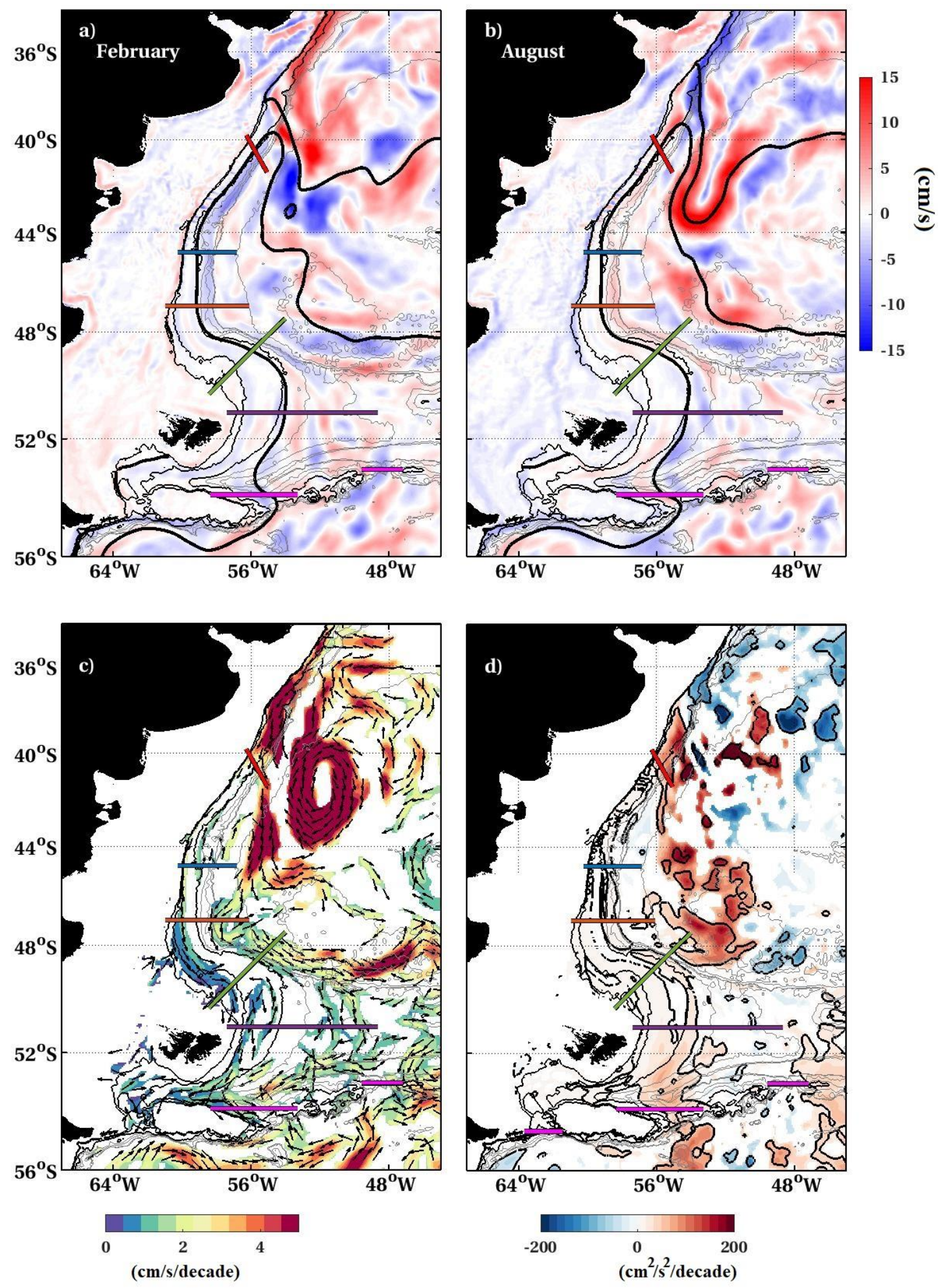



Figure 5 

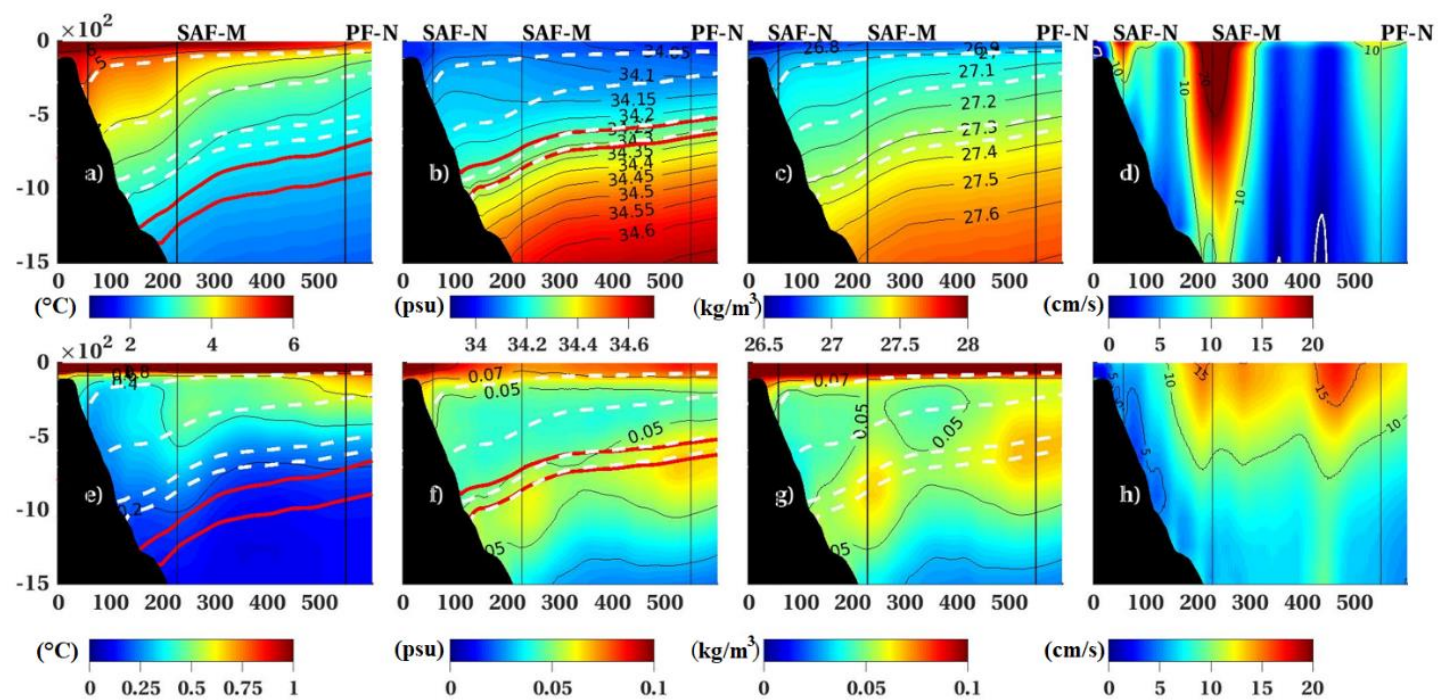

$(\mathrm{cm} / \mathrm{s})$
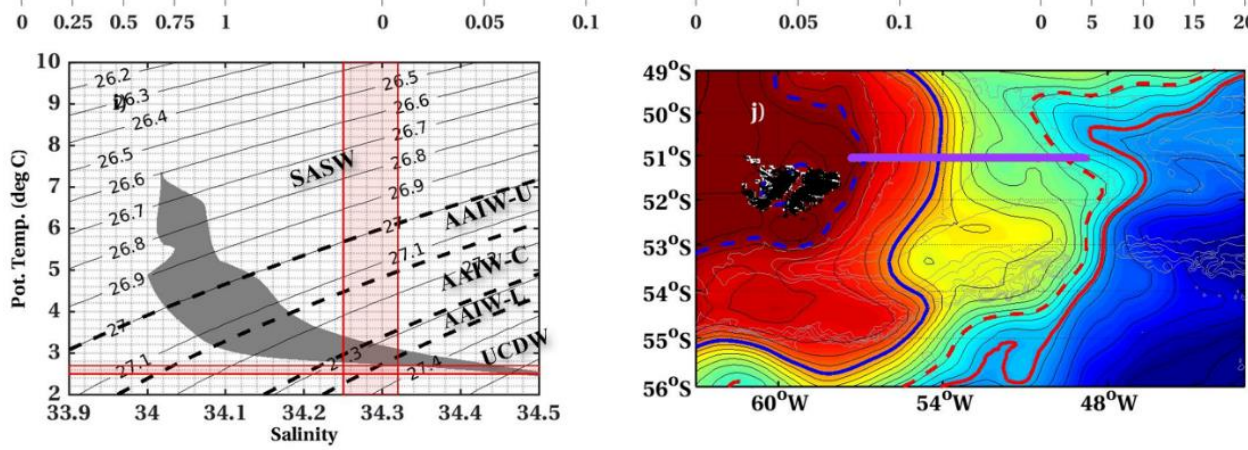

- $\widehat{\Xi}$

Figure 6

895

896

897

898

899

900

901

902

903

904 


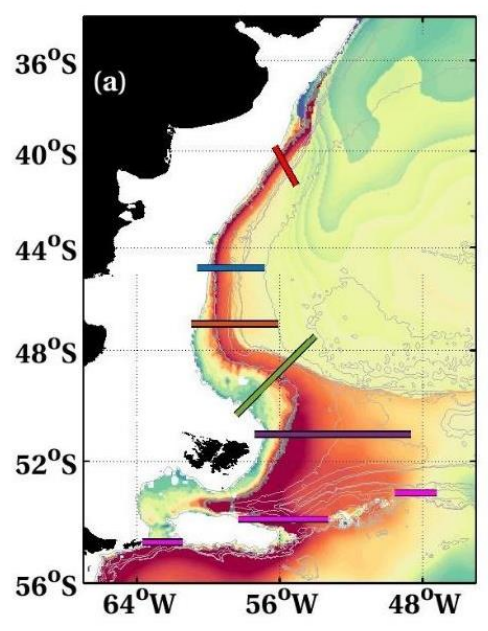

$\begin{array}{lllll}200 & 400 & 600 & 800 & 1000\end{array}$

(m)

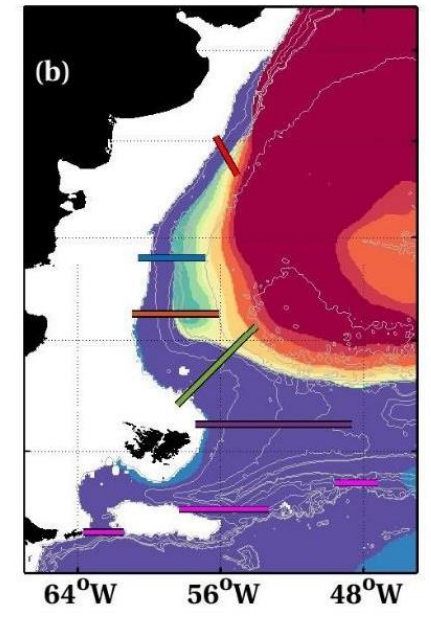

\begin{tabular}{llllll}
\hline & 100 & 200 & 300 & 400 & 500
\end{tabular}

(m)
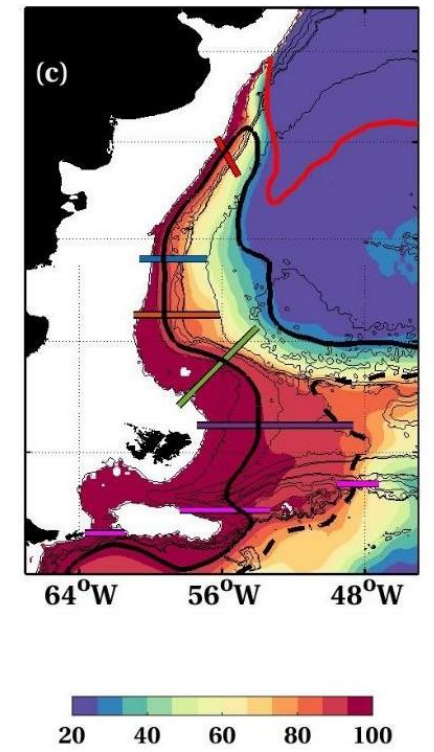

(\%)
905

906

907

908

909

910

911

912

913

Figure 7 

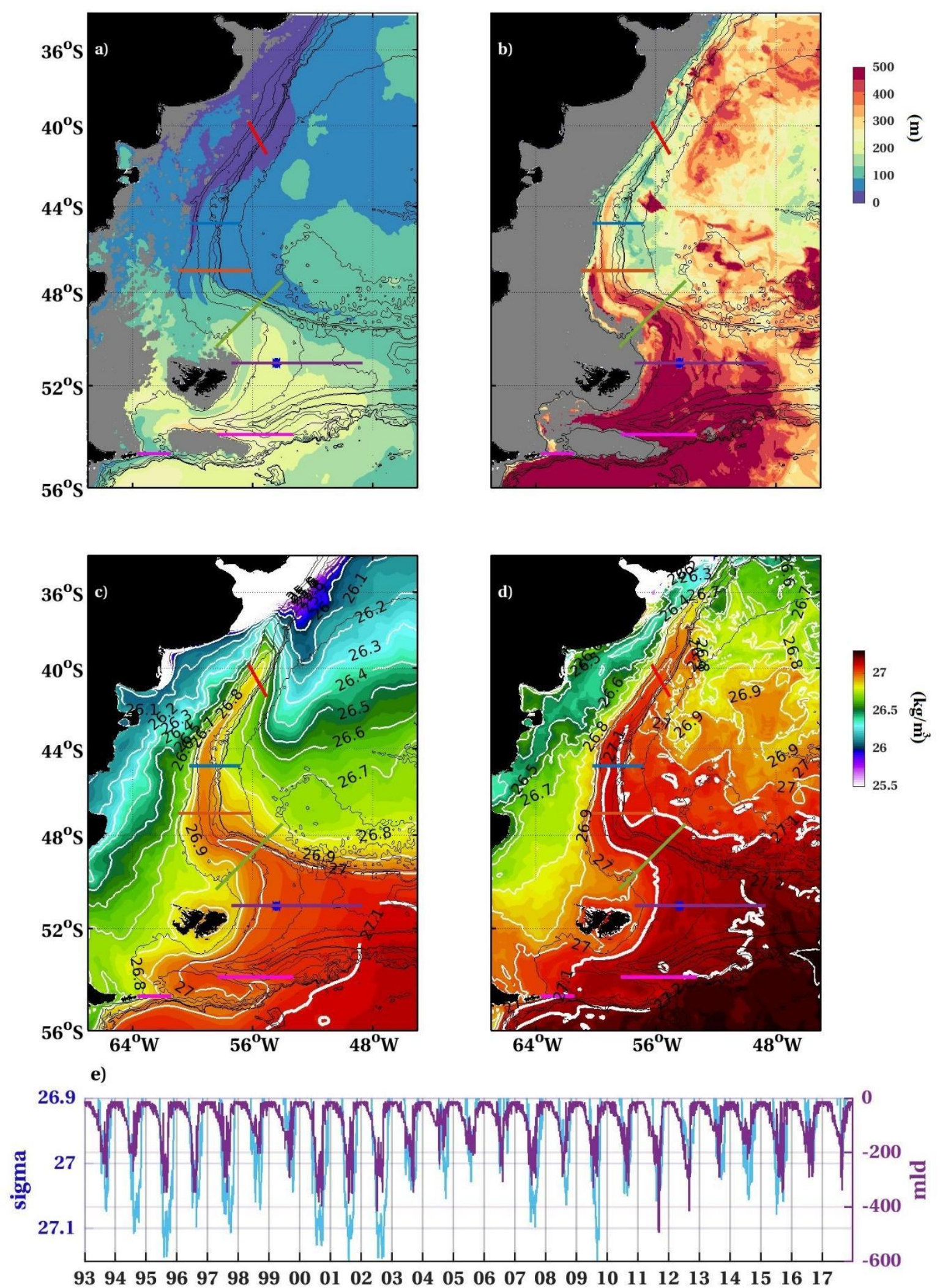

914

915

Figure 8 

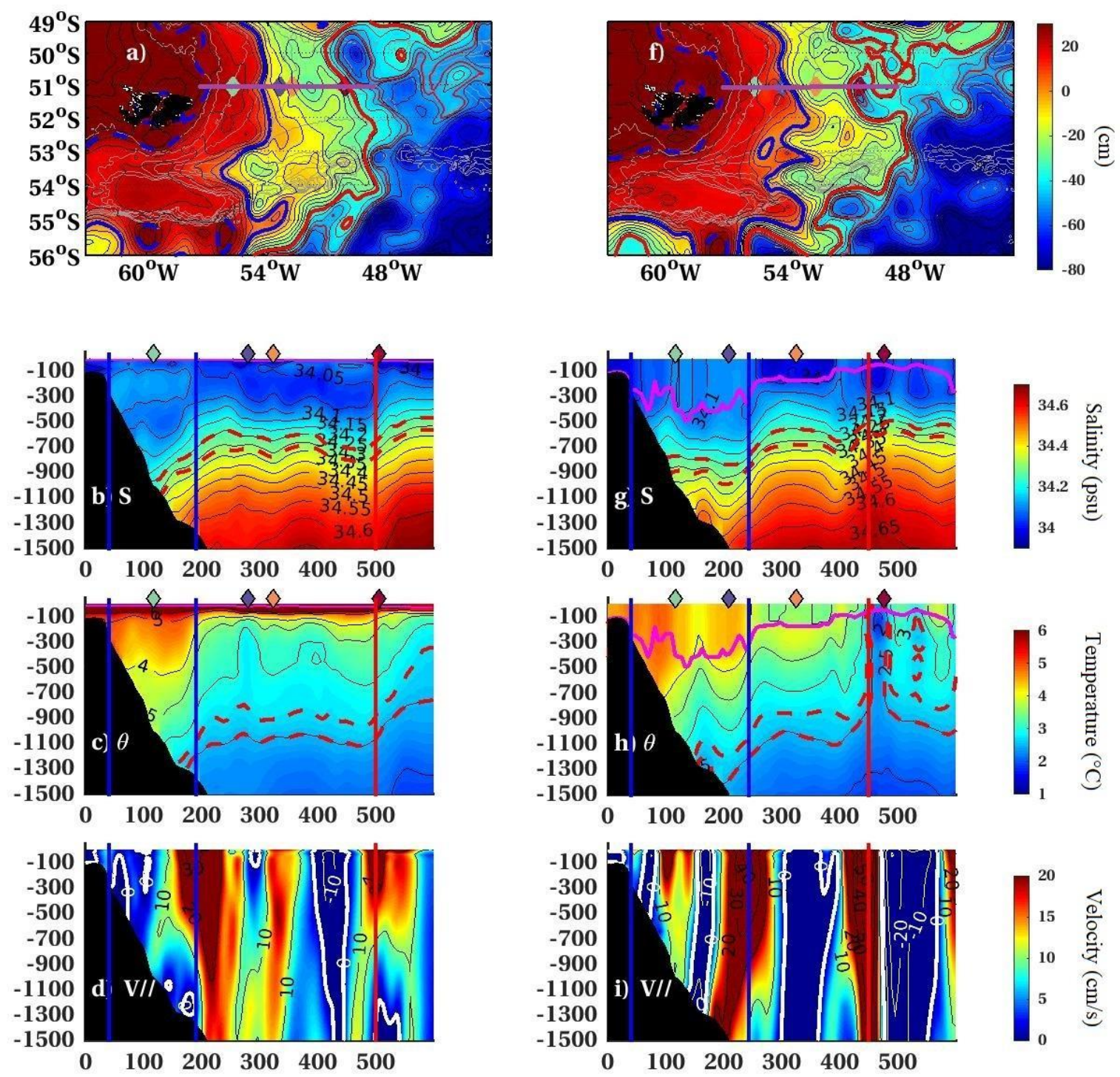

e)
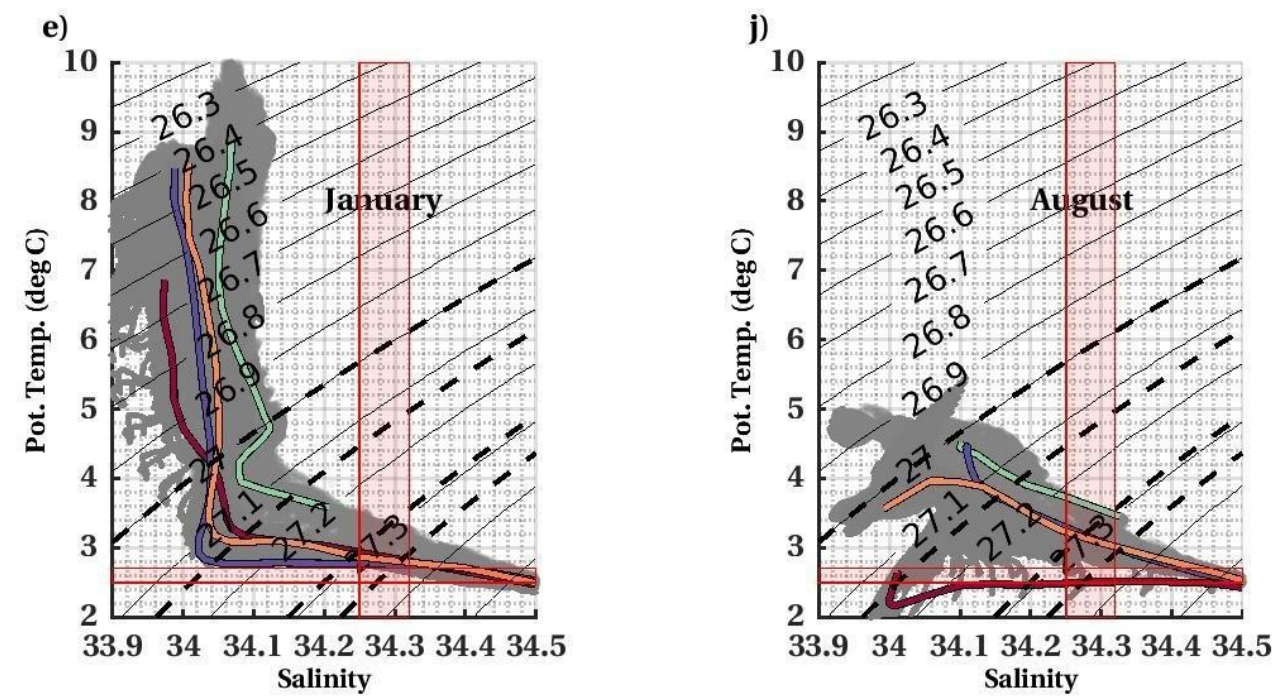

916

917

Figure 9

918 

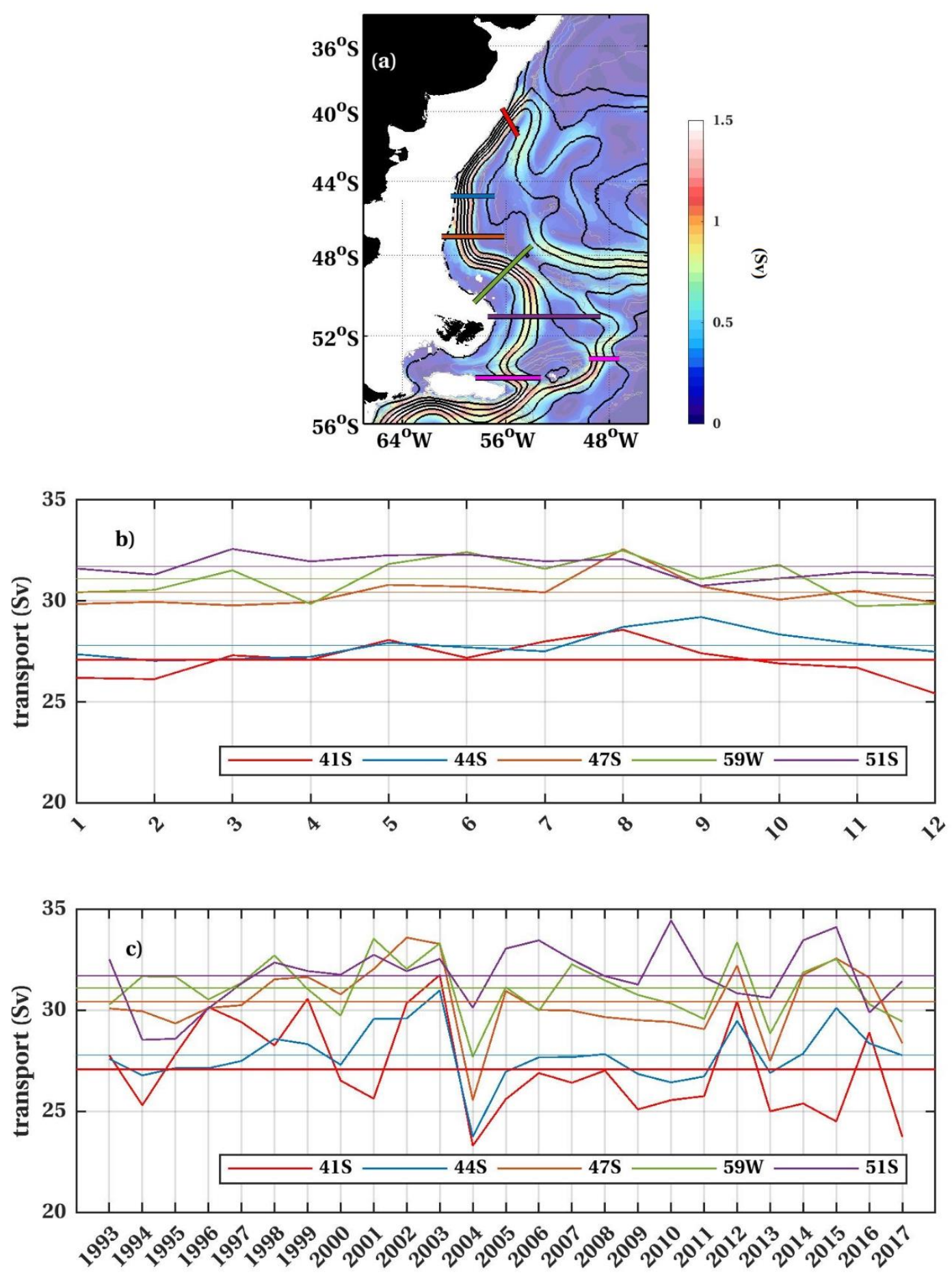

919

920

921

922

Figure 10

923 

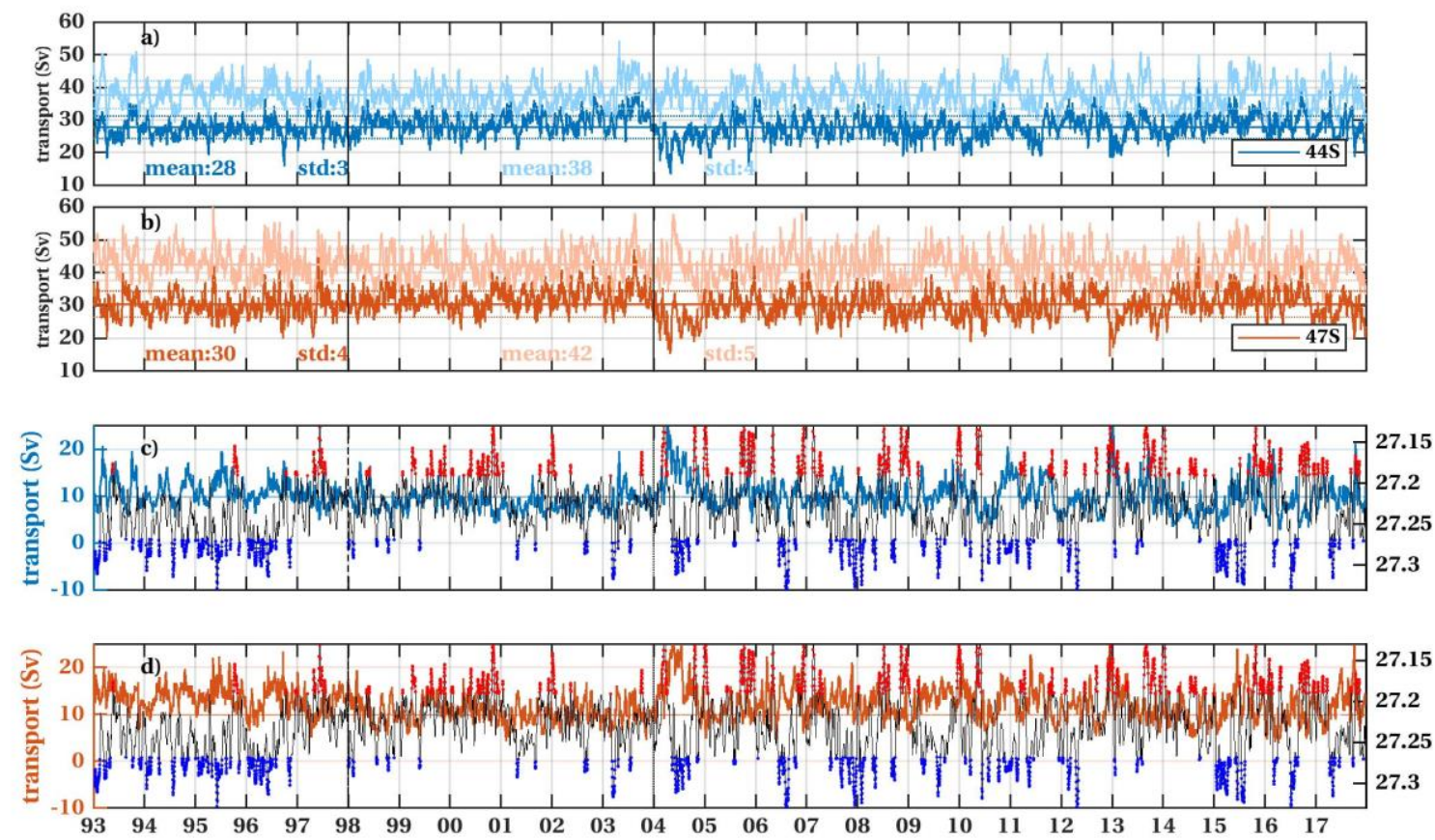

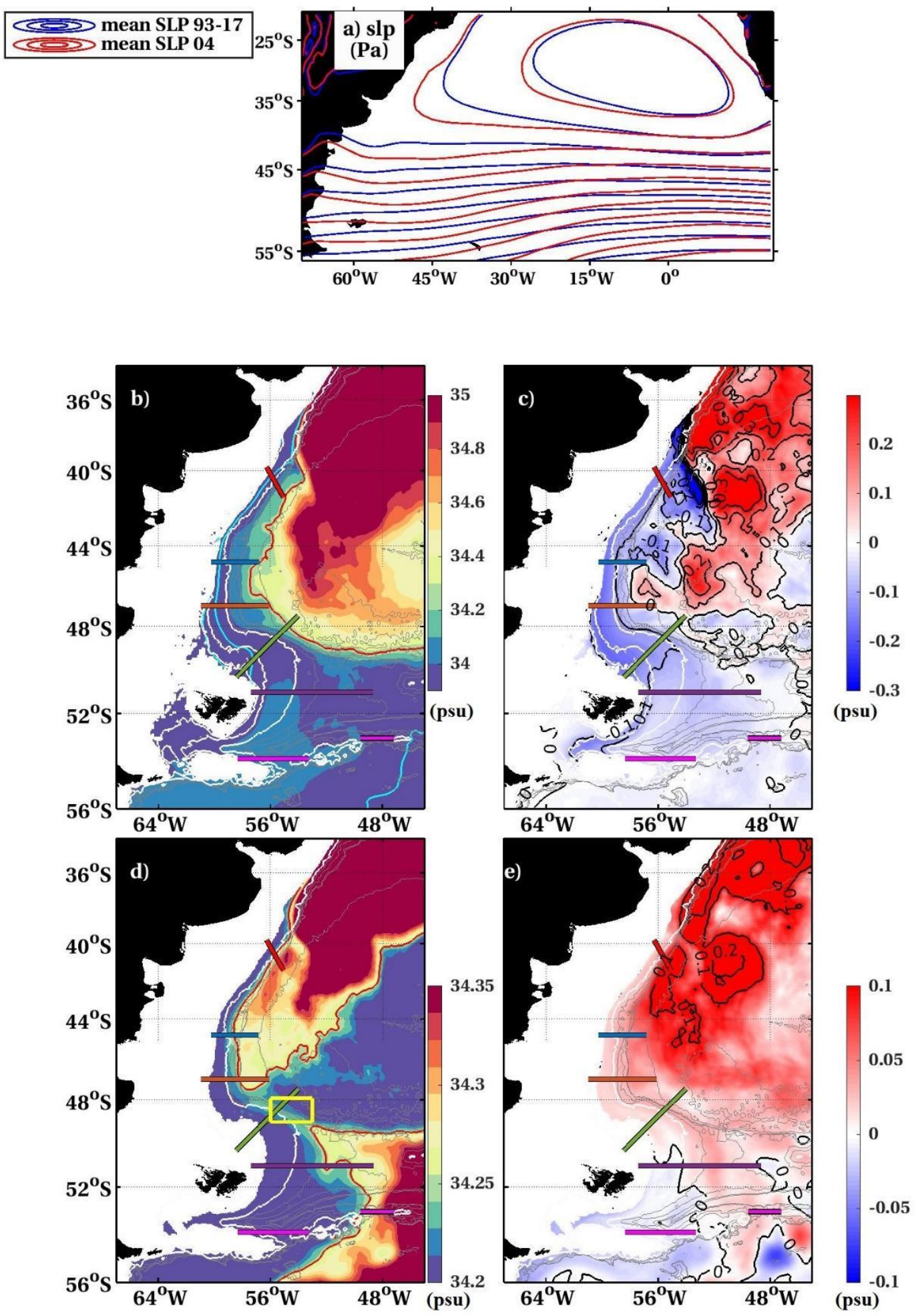

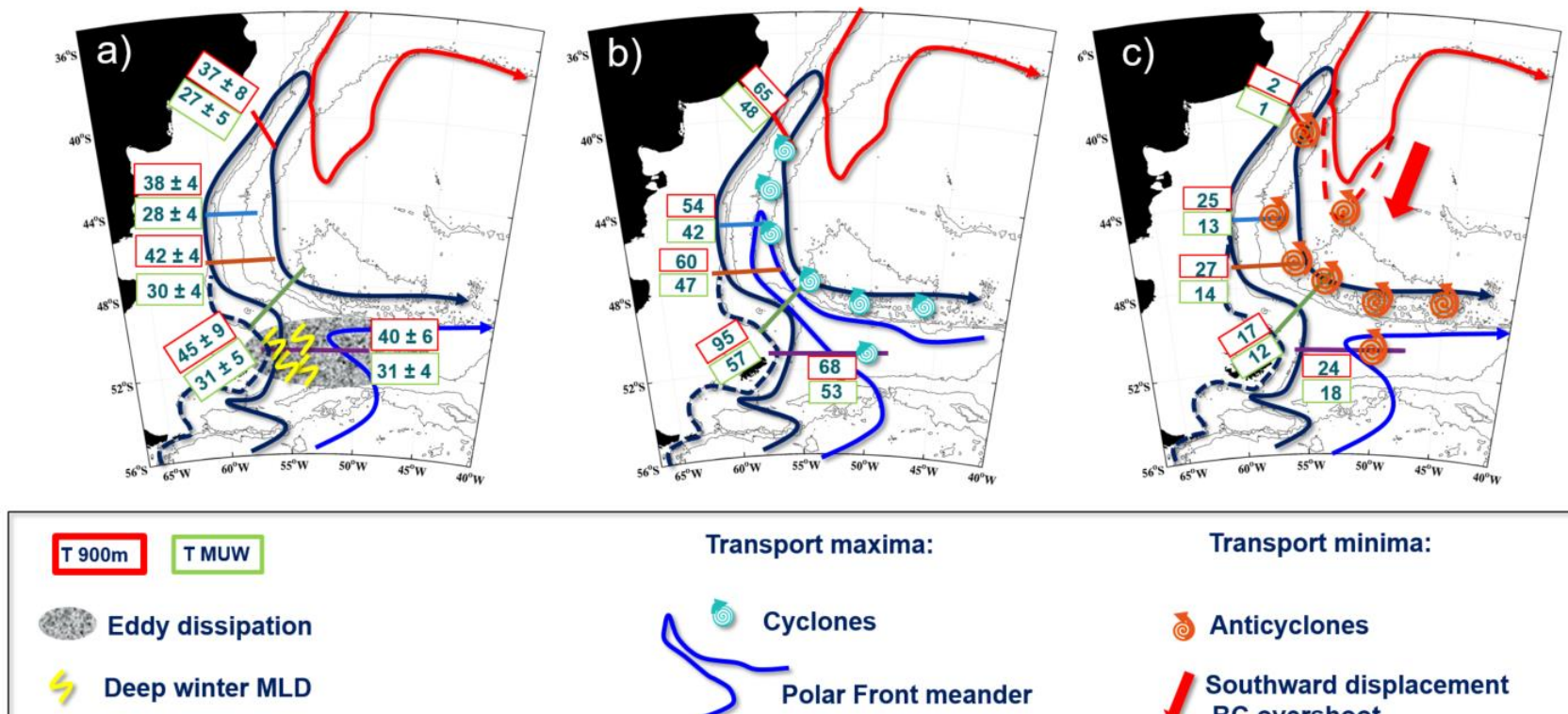

\section{Transport maxima:}

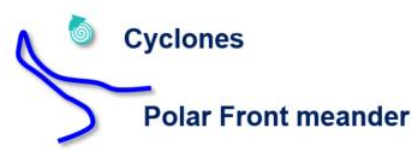

Transport minima:

ङ Anticyclones

Southward displacement BC overshoot

932

933

934

935

Figure 13

936

937

938

939

940

941

942

943

944

945

946

947

948

949 
Tables:

951

952

\begin{tabular}{|c|c|c|c|c|c|c|c|}
\hline \multirow[t]{2}{*}{ section } & \multicolumn{7}{|c|}{ Upper $900 \mathrm{~m}$ volume transport $(\mathrm{T}+) /(\mathrm{T}+-)$} \\
\hline & $\begin{array}{c}\text { mean } \\
(\mathrm{Sv})\end{array}$ & $\begin{array}{c}\text { std } \\
\text { (Sv) }\end{array}$ & $\begin{array}{c}\text { Mean } \\
\text { seasonal } \\
\text { range } \\
(\mathrm{Sv})\end{array}$ & $\begin{array}{l}\text { Interanual } \\
\text { range } \\
(\mathrm{Sv})\end{array}$ & $\begin{array}{c}\text { Synoptic } \\
\max \\
(\mathbf{S v})\end{array}$ & $\begin{array}{c}\text { Synoptic } \\
\text { min } \\
\text { (Sv) }\end{array}$ & $\mathbf{r}$ \\
\hline $41^{\circ} \mathrm{S}$ & $37 / 30$ & $8 / 13$ & $5 / 7$ & $14 / 30$ & $65 / 65$ & $2 /-25$ & 0.86 \\
\hline $44.7^{\circ} \mathrm{S}$ & $38 / 29$ & $4 / 8$ & $3 / 4$ & $6 / 16$ & $54 / 52$ & $25 /-7$ & 0.62 \\
\hline $47^{\circ} \mathrm{S}$ & $42 / 37$ & $4 / 6$ & $5 / 5$ & $5 / 8$ & $60 / 58$ & 27/13 & 0.80 \\
\hline $59^{\circ} \mathbf{W}$ & $45 / 35$ & 9/15 & $5 / 8$ & $9 / 13$ & 95/95 & $17 /-20$ & 0.85 \\
\hline $51^{\circ} \mathrm{S}$ & $40 / 34$ & $6 / 9$ & $3 / 4$ & $8 / 8$ & 68/57 & $24 / 8$ & 0.73 \\
\hline EBB & $23 / 20$ & $6 / 6$ & $4 / 4$ & $7 / 6$ & $57 / 55$ & $7 / 4$ & 0.86 \\
\hline SRP & $31 / 30$ & $7 / 7$ & $5 / 5$ & 9/10 & $55 / 55$ & $6 / 0$ & 0.91 \\
\hline WBB & $3 / 1$ & $1 / 1$ & $1 / 1$ & $1 / 1$ & $7 / 6$ & $0 /-1$ & 0.97 \\
\hline $\begin{array}{c}\text { EBB } \\
+ \text { +SRP+ } \\
\text { WBB }\end{array}$ & $57 / 51$ & $8 / 8$ & $7 / 4$ & 9/7 & 93/90 & $33 / 22$ & 0.92 \\
\hline
\end{tabular}

Table1:

953 
975

\begin{tabular}{|l|l|l|l|l|l|}
\hline & $41^{\circ} \mathrm{S}$ & $44^{\circ} \mathrm{S}$ & $47^{\circ} \mathrm{S}$ & $59^{\circ} \mathrm{W}$ & $51^{\circ} \mathrm{S}$ \\
\hline $41^{\circ} \mathrm{S}$ & & 0.13 & 0.15 & 0.11 & 0.12 \\
& & 0.59 & 0.27 & 0.16 & 0.17 \\
\hline $44.7^{\circ} \mathrm{S}$ & & & 0.30 & 0.16 & $\mathrm{NS}$ \\
& & & 0.54 & 0.30 & 0.20 \\
\hline $47^{\circ} \mathrm{S}$ & & & & 0.37 & 0.12 \\
& & & & 0.44 & 0.21 \\
\hline $59^{\circ} \mathrm{W}$ & & & & & 0.14 \\
& & & & & 0.18 \\
\hline
\end{tabular}

976

977

978

979

980

981

982

983

984

985

986

987

988

989

990

991

992

993

994

995

996

997

998

999

1000

1001

1002

1003

1004

1005

1006

1007

1008

1009

1010

1011 
1012

1013

1014

1015

1016

1017

1018

1019

1020

1021

1022

1023

1024

1025

1026

1027

1028

1029

1030

1031

1032

Table 3

\begin{tabular}{|c|c|c|c|c|c|}
\hline \multirow[t]{2}{*}{ section } & \multicolumn{5}{|c|}{ Volume transports $\mathbf{T}+/ \mathbf{T}+-$} \\
\hline & $\begin{array}{c}\text { mean } \\
(\mathrm{Sv})\end{array}$ & $\begin{array}{l}\text { std } \\
(\mathrm{Sv})\end{array}$ & $\begin{array}{l}\max \\
(\mathrm{Sv})\end{array}$ & $\min _{(\mathrm{Sv})}$ & $\mathbf{r}$ \\
\hline $41^{\circ} \mathrm{S}$ & $27 / 23$ & $5 / 7$ & $48 / 48$ & $1 /-6$ & 0.86 \\
\hline $44.7^{\circ} \mathrm{S}$ & $28 / 23$ & $3 / 5$ & 42/39 & 13/-0.9 & 0.71 \\
\hline $47^{\circ} \mathrm{S}$ & $30 / 27$ & $4 / 4$ & $47 / 46$ & $14 / 7$ & 0.87 \\
\hline $59^{\circ} \mathrm{W}$ & $31 / 25$ & $5 / 8$ & $57 / 57$ & $12 /-3$ & 0.84 \\
\hline $51^{\circ} \mathrm{S}$ & $31 / 27$ & $4 / 4$ & $53 / 44$ & $18 / 7$ & 0.74 \\
\hline EBB & $20 / 17$ & $6 / 4$ & $41 / 35$ & $6 / 4$ & 0.90 \\
\hline SRP & $15 / 15$ & $4 / 6$ & $40 / 40$ & $0 / 4$ & 0.99 \\
\hline WBB & $2 / 1$ & $0.9 / 0.7$ & $6 / 5$ & $0.3 /-1$ & 0.87 \\
\hline $\begin{array}{l}\mathrm{EBB} \\
+\mathrm{SRP}+\mathrm{WBB}\end{array}$ & $38 / 34$ & $7 / 6$ & $63 / 59$ & $17 / 9$ & 0.94 \\
\hline
\end{tabular}

